\title{
A CITRICULTURA NO ESTADO DA BAHIA: UMA ANÁLISE ECONOMÉTRICA DA OFERTA E DA DEMANDA DE LARANJA
}

\author{
CARLOS AUGUSTO PEREIRA FILHO \\ Engenheiro Agrônomo - EMBRAPA
}

Orientador: FERNANDO CURI PERES

Dissertação apresentada à Escola Superior de Agricultura "Luiz de Queiroz" da Universidade de São Paulo, para obtenção do título de Mestre em Economia Agrária.

PIRACICABA

Estado de São Paulo, Brasil Junho, 1980 
A Aurora, Bruno e Taís; aos meus pais (Carlos Augusto e Maria) e à minha sogra (Maria) d e d i c o . . . 


\section{AGRADECIMENTOS}

Desde o inicio do curso de mestrado até a conclu são do presente trabalho, necessitei e obtive a colaboração de vārias pessoas e instituições às quais expresso a minha gratidão:

A Empresa Brasileira de Pesquisa Agropecuāria EMBRAPA, pela oportunidade que me concedeu para realização do curso de mestrado e pelo apoio financeiro;

Ao Departamento de Economia e Sociologia Rural da Escola Superior de Agricultura "Luiz de Queiroz", por terme aceito como aluno, e aos seus professores pelos valiosos ensinamentos;

Ao Professor Fernando Curi Peres - orientador pela colaboração constante na realização deste trabalho e pela amizade;

Aos pesquisadores Almir Pinto Cunha Sobrinho, Orlando Sampaio Passos e Ygor da Silva Coelho, da EMBRAPA, com os quais tive oportunidade de discutir vários aspectos deste trabalho, tendo recebido valiosas sugestões. 
I $N$ D I $I C E$

pàg.

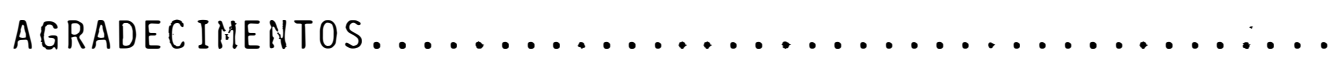

RESUMO $\ldots \ldots \ldots \ldots \ldots \ldots \ldots \ldots \ldots \ldots \ldots \ldots \ldots \ldots \ldots \ldots \ldots \ldots$

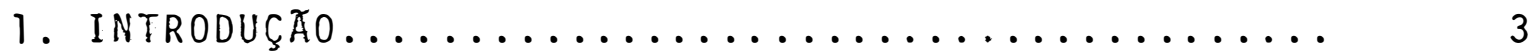

1.1 - o Problema e sua importāncia.............. 3

1.2 - Aspectos da citricultura brasileira........ 6

1.3 - A citricultura no Estado da Bahia......... 13

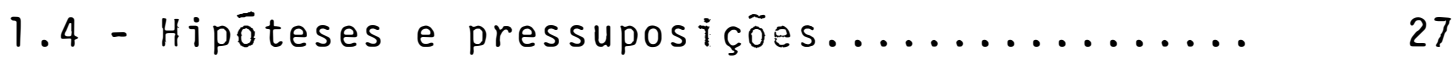

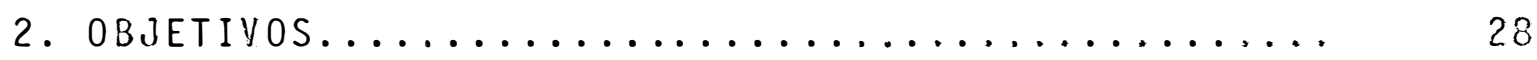

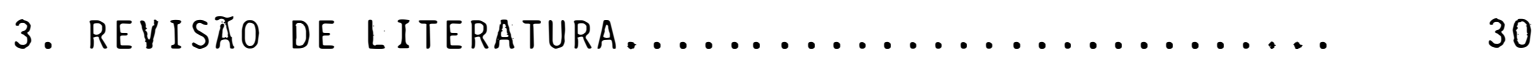

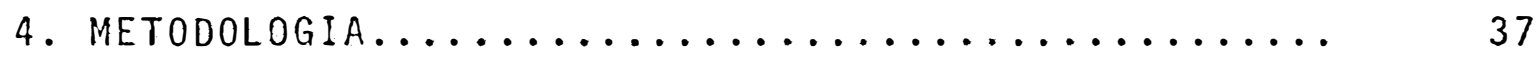

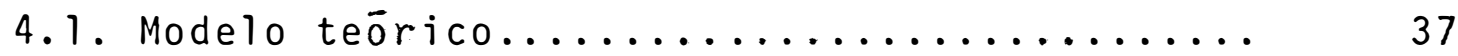

4.1.1 - Equilíbrio dinämico c/ajustamento defasado................. 37

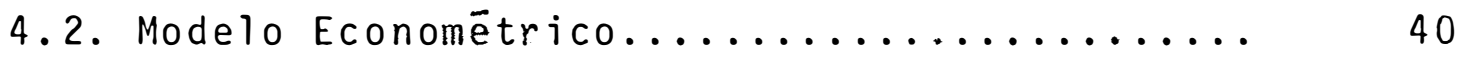

4.2.1 - Modelo de resposta da ārea com de

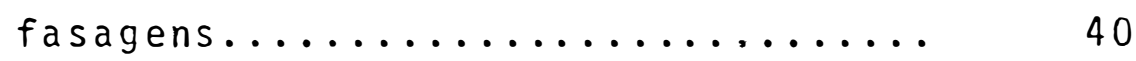

4.2 .2 - Modelos de demanda............. 42

4.3. Definição das variāveis e dados utilizados.. 43

5. RESUltados E Discussós................... 48

5.1. Resposta da ārea com defasagens distribuídas 48

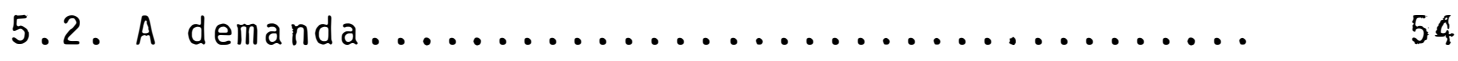

5.3. Dificuldades e limitações................ 61

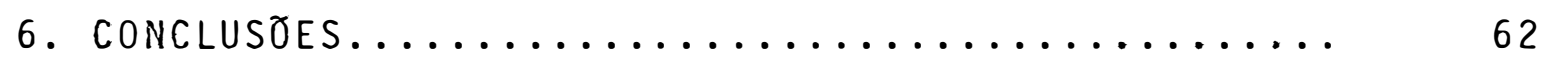

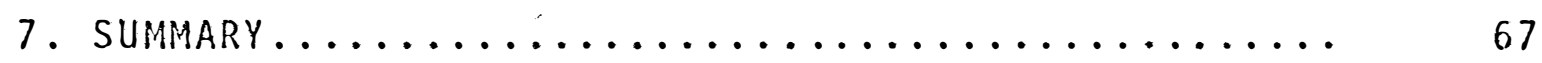

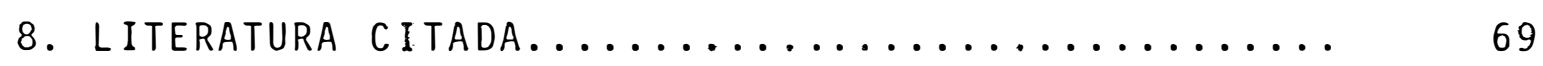

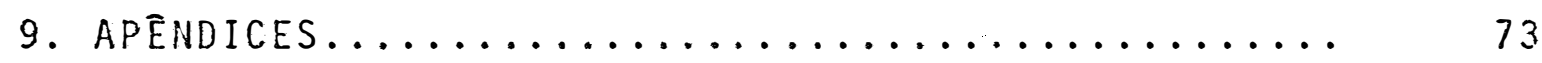




\section{LISTA. DAS TABELAS}

TABELA

Pág.

1 Area colhida, produção e rendimento da laranja nos princi pais estados produtores brasileiros - 1977 .............

2 Produção e exportação de laranja no Brasil .............

3 Exportações brasileiras de frutas cîtricas, 1969/1978 ...

4 Consumo de frutas citricas no Brasil - $1977 \ldots . . . . . . . . . \quad 14$

5 Zonas citrícolas do Estado da Bahia .................

6 Taxas médias anuais de crescimento da área colhida e da produção de laranja no Estado da Bahia ................

7 Importação e exportação de laranja no Estado da Bahia -

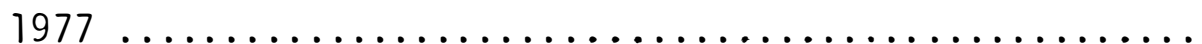

8 Preços médios anuais de laranja, a nĩvel de produtor, nos Estados da Bahia e de São Paulo, no período de 1971 a 1976

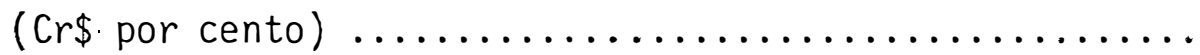

9 Estimativa dos parâmetros do modelo ajustado de resposta da área colhida de laranja. Éstado da Bahia, período 1947

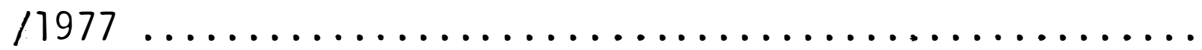

10 Estimativa dos parâmetros dos modelos de demanda de laran ja, a nível de atacado. Estado da Bahia, 1975/1978 ...... 
TABELA

pāg.

1.1. Area e quantidade de laranja, preços reais de laranja e fumo. Estado da Bahia, 1947/1977 ...................

2.1. Quantidades de laranjas comercializadas e preços corren tes de laranjas, tangerina, banana e abacaxi, na CEASA

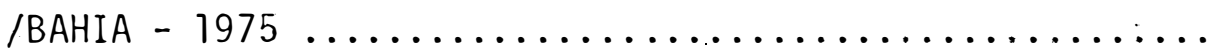

2.2. Quantidades de laranjas comercializadas e preços correntes de laranjas, tangerina, banana, e abacaxi, na CEASA /

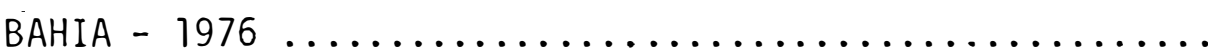

2.3. ?uantidades de laranjas comercializadas e preços correntes de laranjas, tangerina, banana e abacaxi, na CEASA /

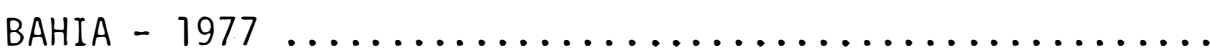

2.4. Quantidades de laranjas comercializadas e preços correntes de laranjas, tangerina, banana e abacaxi, na CEASA / BAHIA - 1978

3.1. Equações alternativas estimadas de resposta de ārea co -

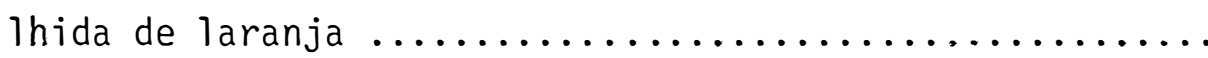

4.1. Equações alternativas estimadas de demanda de laranja a

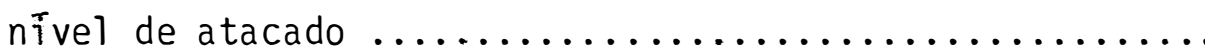

5.1. Matriz de correlações simples entre as variāveis componen tes dos modelos de resposta da área colhida, 1947/1977 ..

6.1. Matriz de correlações simples entre as variāveis componen tes dos modelos de demanda de laranja a nivel de atacado, $1975 / 1978$ 
RESUMO

objetivando analisar as variāveis que afetam a ārea colhida de laranja e a demanda deste produto a nível de atacado, no Estado da Bahia, utilizou-se modelos de ajustamento parcial, com defasagens distribuidas, para se estimar as elasticidades-preço da oferta e da demanda, no curto e longo prazos.

As equações estimadas para ārea colhida foram ex plicitadas para as variāveis preços reais de laranja e fumo de fasadas em 3 anos, e ārea colhida de laranja defasada de 3 anos. Afim de melhor analisar o efeito do preço da laranja na ārea colnida ao longo do tempo, utilizou-se uma variável "dummy" pa ra intercepto e inclinação de modo a seccionar a sērie de da-l dos em 2 periodos, adnitindo-se que a resposta da ārea ao preço é distinta entre os períodos 1950/65 e 1966/77. As estimati vas obtidas resultaram em - respostas não significativas às variāveis preço da laranja e preço do fumo. Acredita-se que 
tenha ocorrido problemas de multicolinearidade, impedindo a ob tenção de estimativas consistentes atravēs da aplicação de mî nimos quadrados ordinārios.

Em relação à demanda de laranjas a nível de ata cado, as variáveis independentes consideradas (preços reais de laranja, tangerina, banana e abacaxi, e quantidade de laranja defasada de 1 més), apresentaram alto grau de explicação das variações nas quantidades adquiridas no mercado atacadista. os resultados evidenciaram que a demanda por laranja apresenta inelasticidade-preço e baixa competitivamente com o abacaxi. A inclusão de variāvel "dummy" para captar delocamentos de demanda devido a mudança de estação (inverno-verão) nao apresentou diferenças significativas. Uma outra variāvel "dummy" evidenciou diferença significativa para deslocamento da função de demanda quando a variedade 'Bahia' predomina no mercado sobre a variedade 'Pera'. 
1. INTRODUÇÃO

1.1. O problema e sua importāncia.

Nas ūitimas duas décadas, a citricultura brasi leira vem apresentando aumentos contínuos de produção. 0 cres cimento das demandas externa e incerna estimulou a expansão da citricultura, colocando o Brasil nas posições de segundo maior produtor mundial de citros e de primeiro exportador de suco concentrado.

As perspectivas de aumento das exportações, tan to pela ampliação dos mercados tradicionais como pelas possibi lidades de novos mercados, e o crescimento da demanda interna, levam a crer que a oferta de citros ainda deverá se expandir consideravelmente nos próximos anos.

Alguns problemas, contudo, poderão vir a reduzir o ritmo de expansão da oferta e, consequentemente, as expor tações e o suprimento interno. Entre estes, os altos retornos 
esperados com outras culturas como o café, a cana-de-açūcar, a soja e a pecuāria, poderão induzir a uma substituição da citrị cultura em algumas āreas, como tambēm alterar as relações de preços de fatores de produção como terra, mão-de-obra e insumos, elevando os custos de produção de citros, principalmente no Es tado de São Paulo onde se concentra cerca de $70 \%$ da produção brasileira. Alēm disso, existe ainda o perigo de expansão do "cancro citrico" que, por si sō, jā se constitue um fator 1 im tante para a ampliação da área cultivada na região sudeste do Brasil.

A região nordeste do Brasil apresenta-se como uma alternativa viável para a expansão da produção de citros, tanto para o mercado interno como para o mercado externo, prin cipalmente se se considera a disponibilidade de āreas nas zonas propícias à cultura.

Um dos fatores considerados como limitantes $\bar{a}$ viabilização da citricultura nordestina para exportação refere se à qualidade dos frutos, mormente em relação à coloração e ao balanceamento acidez-sōlidos solūveis, problemas estes que poderão ser solucionados atravēs da pesquisa. Em relação ao mercado interno, as perspectivas apresentam-se favorāveis, prin cipalmente na prōpria região nordeste onde o consumo vem cres cendo consideravelmente.

A citricultura nordestina vem apresentando, nos ūitimos anos, uma considerável tendēncia expansionista, aumen tando, gradativamente, a sua participação na produção brasilei 
ra. Os estados de Bahia e Sergipe lideram a produção nordesti na, destacando-se o segundo como o principal supridor de laran jas para o mercado regional.

No Estado de Sergipe, onde as mais altas taxas de crescimento da citricultura foram observadas nos últimos anos, a possibilidade de expandir ainda mais a cultura é res tringida pela reduzida disponibilidade de áreas propícias à ex ploração de citros.

Quanto à ärea disponīvel, o Estado da Bahia apre senta melhores perspectivas que o Estado de Sergipe. Ademais, algumas outras condições parecem assegurar a tendencia crescen te da citricultura baiana. O crescimento do consumo de citros, principalmente laranjas, tanto no Estado da Bahia como no Nor deste como um todo, tem pressionado a oferta, estimulada, ainda, pela possibilidade de produção a custos mais baixos em relação à região sudeste, mormente quando se considera os fatores ter ra e mão-de-obra. Por outro lado, a localização neste Estado do Centro Nacional de Pesquisa de Mandioca e Fruticultura, da EMBRAPA, enfatizando a pesquisa emcitricultura, é uma garantia do suporte tecnológico necessário ao desenvolvimento da cultu ra.

Considerando a situação atual da citricultura no Estado da Bahia e as mudanças que vêm ocorrendo nos processos de produção e comercialização, a especificação de um modelo econōmico que explique as relações estruturais de oferta e de manda de citros é de grande validade como instrumentos de or $\dot{q}$ 
entação de politicas e programas de desenvolvimento da produção e comercialização.

A anālise das relações de mercado para produtos agrícolas tem sido objeto de continuo estudo e discussões em diversos países. Contudo, apesar da importāncia do problema, o número de estudos existentes ainda é bastante pequeno, princi palmente em referência a culturas perenes.

Para o Estado da Bahia, não foram encontradas re ferências a estudos relacionados à anālise das estruturas de oferta e demanda de citros.

As perspectivas da citricultura brasileira, e a baiana principalmente, são analisadas a seguir, visando estabe lecer um quadro referencial para a análise da oferta e da de manda.

\subsection{Aspectos da citricultura brasileira}

A histōria da citricultura no Brasil remonta da época do descobrimento. A sua introdução foi feita pelos portu gueses, por volta de 1530. PASSOS et al (1978) afirmam que so mente após o ano de 1900 é que foram estabelecidos pomares co merciais, nos Estados de São Paulo, Rio de Janeiro e outros.

As plantas citricas pelo fato de adaptarem-se às condições climáticas mais diversas, distribuem-se por todos os estados brasileiros. Contudo, segundo REUTHER (1977), 92\% da área cultivada e $91 \%$ da produção do Brasil localizam-se em re 
giões sub-tropicais.

Entre os citros, a laranja destaca-se como a principal cultura, sendo considerável a sua importāncia para a economia do setor agrícola, representando, aproximadamente, $20 \%$ do valor da produção brasileira de frutas. Merecem destaques os fatos de que o Brasil, em relação ao mundo, ocupa posições previlegiadissimas como 20 maior produtor de citros e maior ex portador de suco concentrado.

O Estado de São Paulo detem, aproximadamente, $70 \%$ da produção brasileira de citros, seguido pelos estados do Rio de Janeiro, Minas Gerais, Rio Grande do Sul, Sergipe e Bahia (Tabela 1).

Nos ūitimos quinze anos, tem sido considerável o crescimento da produção brasileira de citros. Tomando-se o ano de 1960 como base, a produção de laranjas apresentou um cresç $\underline{i}$ mento àcumulado no período de $340,5 \%$ até 1976 quando foram co lhidos, aproximadamente, 36,8 milhões de frutos.

A nivel nacional, embora tenha-se verificado al guns ganhos de produtividade, o crescimento da produção tem-se dado bāsicamente pela expansão da ārea cultivada. Em relação ao rendimento, tem-se observado oscilações ano a ano devido, principalmente, a variações climáticas, ocorrēncia de pragas e doenças e entrada de novos pomares em produção.

Os indices de rendimento da cultura de citros no Brasil são baixos quando comparados a outros paises. A reduzi 
Tabela 1 - Área colhida, produção e rendimento da laranja nos principais estados produtores brasileiros - 1977

\begin{tabular}{lccc}
\hline Estados & $\begin{array}{c}\text { Area colhida } \\
\text { (hectares }\end{array}$ & $\begin{array}{c}\text { Produção } \\
(1.000 \text { frutos) }\end{array}$ & $\begin{array}{c}\text { Rendimento } \\
\text { (Frutos/ha ) }\end{array}$ \\
\hline São Paulo & 286.405 & 25.100 .000 & 87.638 \\
Rio de Janeiro & 35.500 & 2.662 .500 & 75.000 \\
Rio Grande do Sul & 22.500 & 1.715 .625 & 76.250 \\
Minas Gerais & 22.064 & 1.648 .633 & 74.720 \\
Sergipe & 13.050 & 939.600 & 72.000 \\
Bahia & 8.000 & 552.000 & 69.000 \\
Paranā & 5.162 & 480.050 & 92.996 \\
Santa Catarina & 5.102 & 564.557 & 110.654 \\
\hline
\end{tabular}

Fonte: ANUARIO ESTATISTICO DO BRASIL, 1978. 
da utilização de insumos e deficiência no suprimento de mudas selecionadas são, entre outros fatores, pontos de estrangulamen to da citricultura brasileira.

A produção brasileira de citros destina-se ao consumo interno "in natura" e à exportação na forma de frutas frescas e de suco concentrado. Segundo o MINISTERIO DA AGRICUL TURA (1979), as exportações de citros "in natura", sucos cítri cos e sub-produtos atingiram, em 1978, mais de 140 milhões de dólares, correspondendo a cerca de $3 \%$ das divisas geradas com as exportações agro-pecuárias.

As exportações de sucos cītricos, em 1978, corres pondente ao valor de, aproximadamente, 85,3 milhões de dólares (preços FOB), colocaram este produto em 140 lugar na relação dos produtos exportados, contribuindo com $1,46 \%$ do valor total das exportações brasileiras.

A produção de citros para exportação está concen trada no Estado de São Paulo onde, em 1976, a participação da laranja industrializada em relação ao volume comercializado foi de $77,8 \%$, de acordo com estimativas do MINISTÉRIO DA AGRICULTU RA (1979).

Excluindo as do Estado de São Paulo, existem ape nas mais duas indústrias de processamento de citros para suco, uma no Rio Grande do Sul e outra no Estado de Sergipe, ambas com pequena capacidade de processamento.

Em 1977, quase a metade $(49,5 \%)$ da produção bra 
sileira de citros foi comercializada como matéria prima para as indústrias extratoras de sucos. Após o processamento da fruta, cerca de $90 \%$ dos sucos foram exportados, principalmente para a Alemanha Ocidental, Estados Unidos, Países Baixos, Suécia e Canadá (MINISTÉrio da AGRICULTURA, 1978).

Na Tabela 2 são mostradas as quantidades de la ranja exportadas na forma de frutas frescas e suco concentrado.

Apesar de deter o tîtulo de segundo maior produ tor mundial de citros o Brasil não se caracteriza como um gran de exportador de frutas citricas "in natura". Suas exportações não chegam a atingir $2 \%$ do volume das exportações mundiais des te produto, apesar de contar com algumas vantagens como, por exemplo, pico de safra ocorrendo na entressafra dos concorren tes, custos de produção relativamente baixos e qualidade dos produtos. A Tabela 3 relaciona, por espécie, as exportações de frutas cîtricas de 1969 a 1978. De 1972 a 1977 , as exportações brasileiras de citros "in natura" apresentaram uma tendencia nitidamente decrescente, excetuando-se o ano de 1975 quando ve rificou-se um crescimento de $62,5 \%$ em relação ao ano anterior. 0 principal obstáculo ao aumento das exportações de frutas fres cas parece estar relacionado com a má distribuição da oferta de transportes marítimos para algumas promissoras āreas compra doras.

0 mercado interno de produtos citricos restringe se quase que exclusivamente ao produto para consumo "in natura", absorvendo cerca de $50 \%$ da produção total de frutas. 


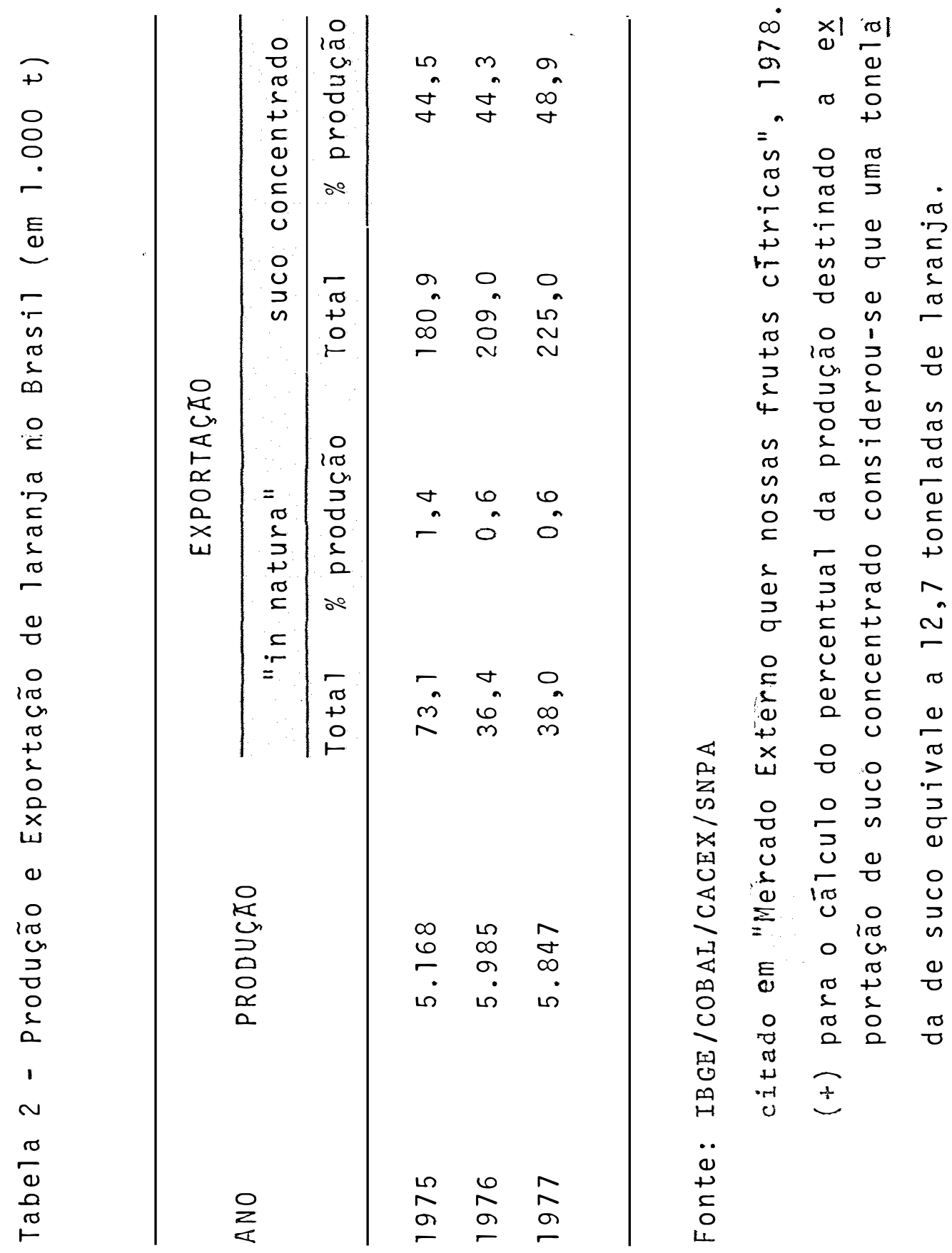


12.

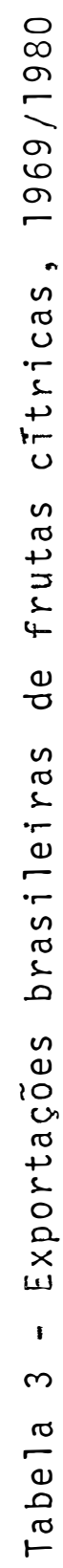

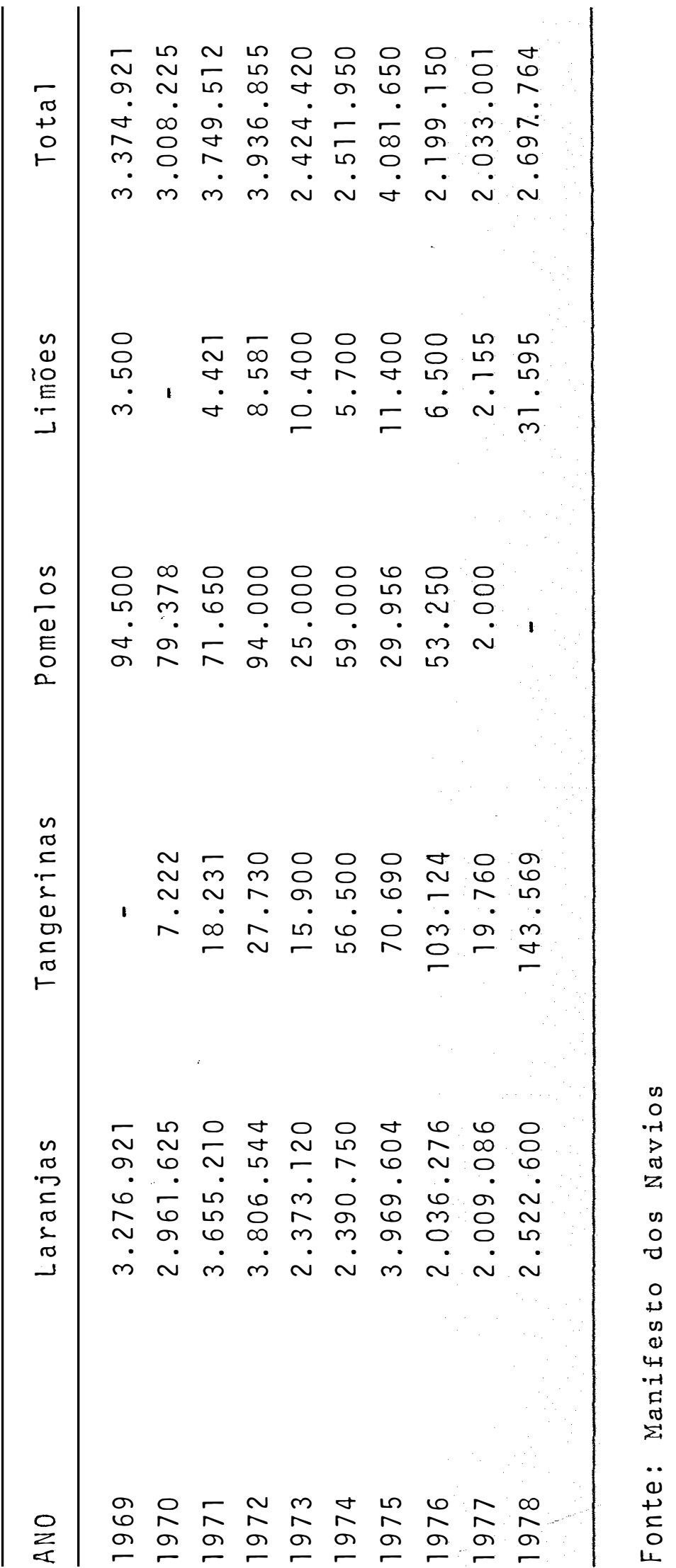


Além de deter o primeiro lugar como produtora de citros, a região sudeste do Brasil é, tambëm, a maior consumi dora, seguida da região Nordeste. Na Tabela 04 são apresentados dados de consumo de citros no Brasil, por região, para o ano de 1977 .

1.3. A citricultura no Estado da Bahia

A produção de citros no Estado da Bahia concen tra-se nas regiões Recóncavo e Litoral Norte, embora seja en contrada em quase todas as regiões do Estado. Na Tabela 5 estão relacionados os municípios que compõem as zonas citrícolas ba $\underline{i}$ anas.

A citricultura baiana caracteriza-se pela predo. minância de pequenos pomares localizados em pequenas proprieda des. Sabe-se que, aproximadamente, $90 \%$ dos pomares têmāreas in feriores a 50 hectares, correspondendo a cerca de $80 \%$ da proau ção total do Estado.

Originalmente, a cultura de laranja desenvolveu se, nas décadas de 20 e 30 , nos municípios de Salvador e Ala goinhas, sendo dizimadas na década de 40 pela doença conhecida como "Tristeza". Na década de 50, deu-se a expansão da cultura na região Recóncavo Baiano que veio a tornar-se a maior e mais importante zona citrícola do Estado.

Nos anos 60 , a citricultura baiana passou por profundas transformações. A implantação em 1961 de um programa 


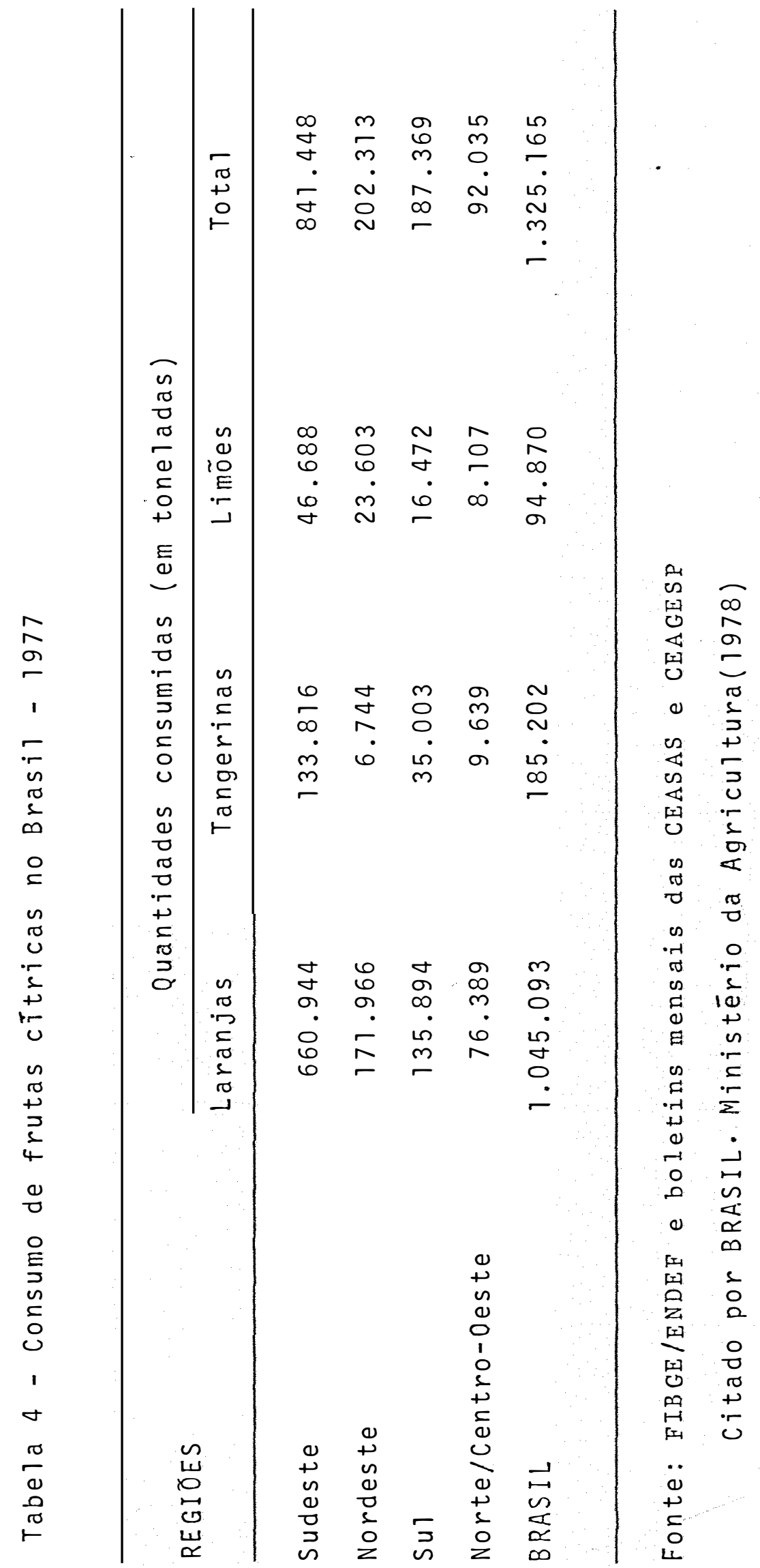




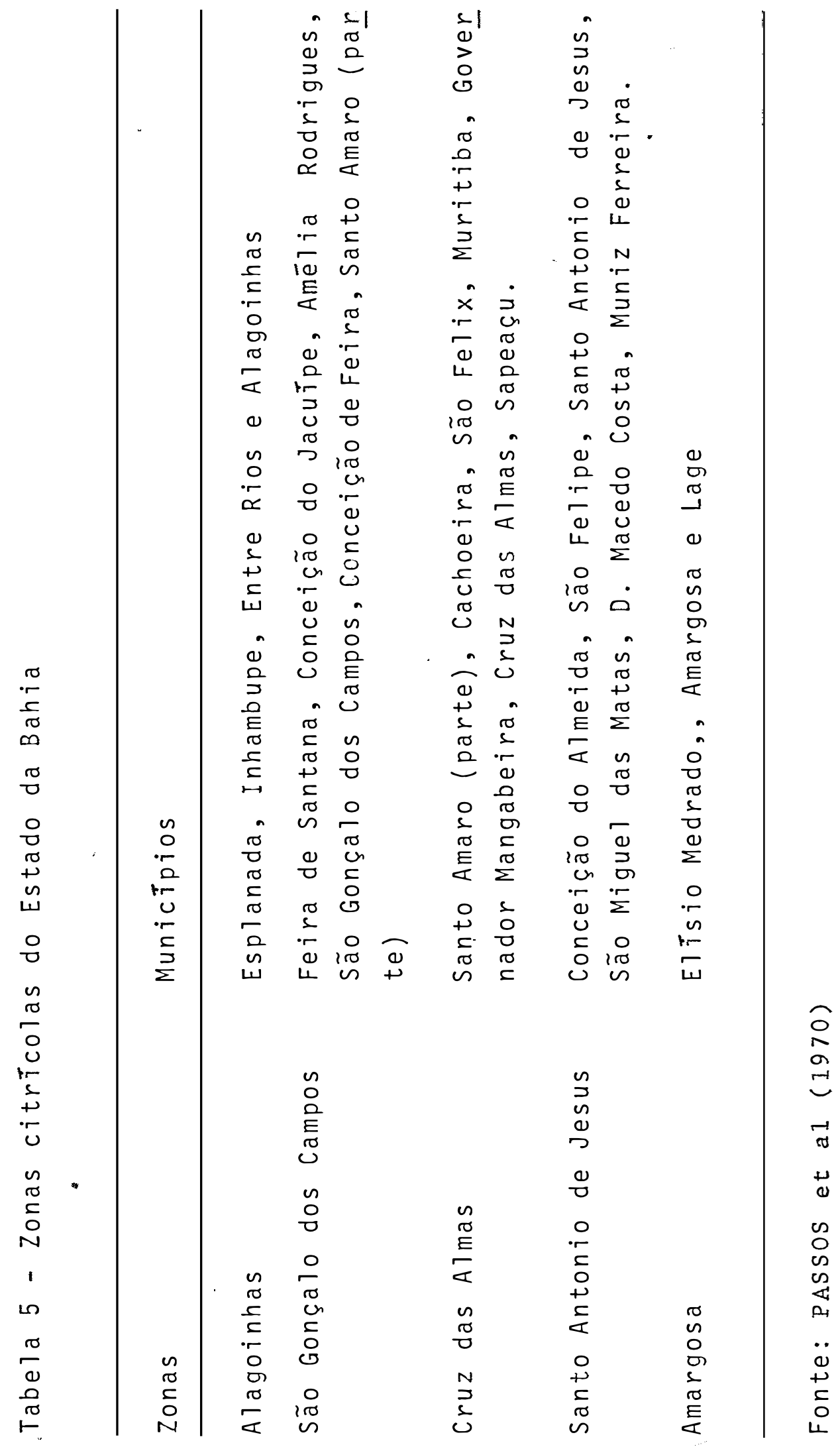


de pesquisa em citros pelo IPEAL (Instituto de Pesquisa e Expe rimentação Agropecuária do Leste), tendo como meta prioritária a obtenção e propagação de clones nucelares de boa qualidade e a introdução de novos cultivares, veio a propiciar o suporte necessārio à modernização da citricultura, completamentada pe la ação do serviço de extensão rural e apoiada na política cre ditícia para o setor que permitiu a efetivação dos investimen tos em novos pomares.

O efeito das politicas supra mencionadas sobre a expansão da citricultura baiana a partir de meados dos anos 60 é evidenciado pelas altas taxas de incremento na área cultiva da e na produção, em relação ao perĩodo anterior (Tabela 6 e Figuras 1 e 2). E interessante ainda observar que o considerá vel crescimento da citricultura neste periodo ocorreumesmo sob condições de preços desfavoráveis ao citricultor. Pode-se ob servar na Figura 3 que os preços apresentaram uma tendéncia de clinante no período de 1958 a 1968, enquanto a ārea e a produ ção cresceram a taxas médias anuais da ordem de $4,6 \%$ e $5 \%$, res pectivamente.

Face ao exposto, parece razoável admitir que, no período acima considerado, outros fatores como politica credi tícia e assistência técnica tenham sido bem mais relevantes do que os preços no crescimento da citricultura. A politica de crédito com juros subsidiados e prazos dilatados para amortiza ção dos empréstimos constituiu-se em fator dos mais importantes para expansão da citricultura. Na zona citrícola de Cruz das 


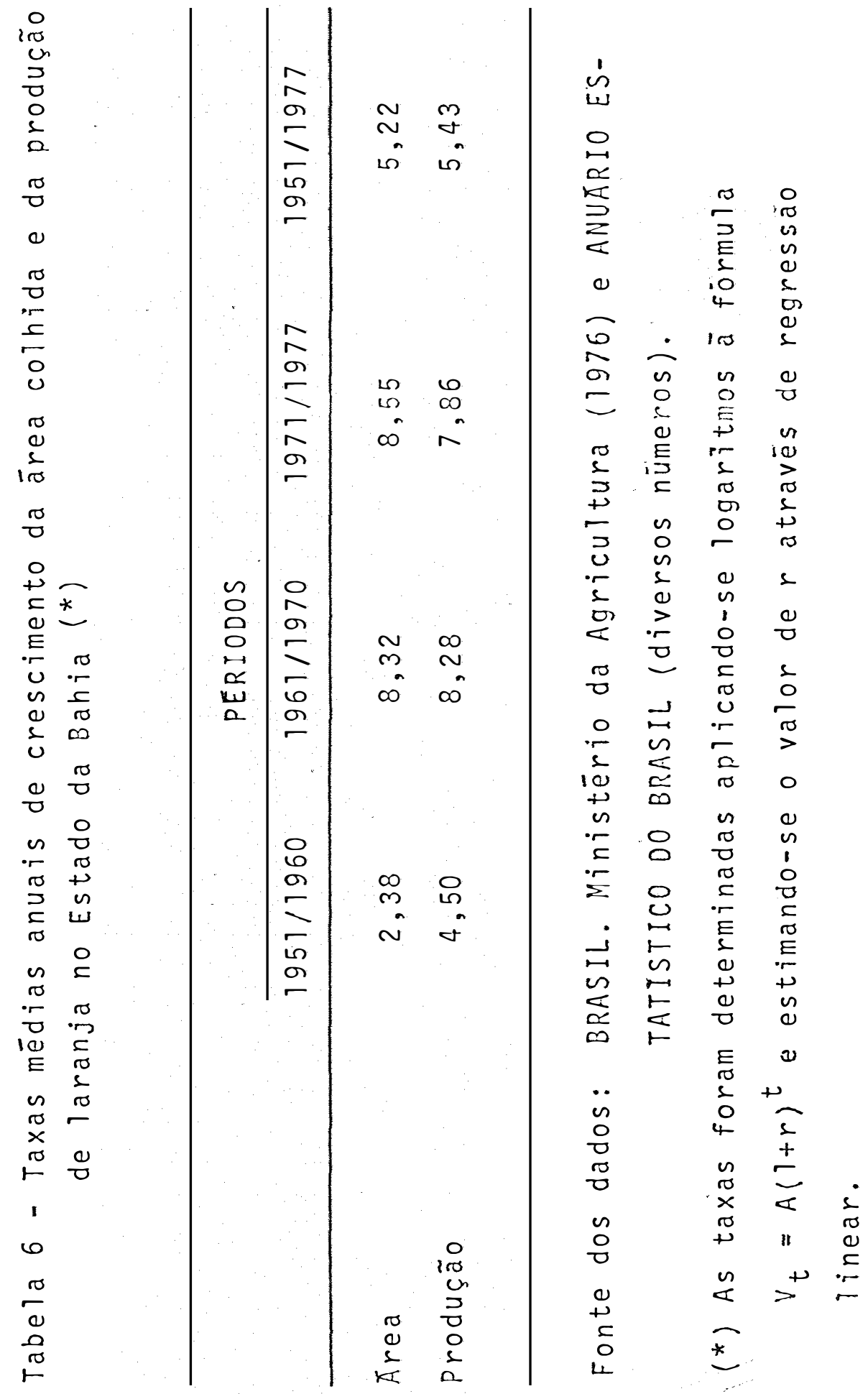


Figura 1: Evolução da área colhida de laranja no Estado da Bahia, período $1950 / 1977$

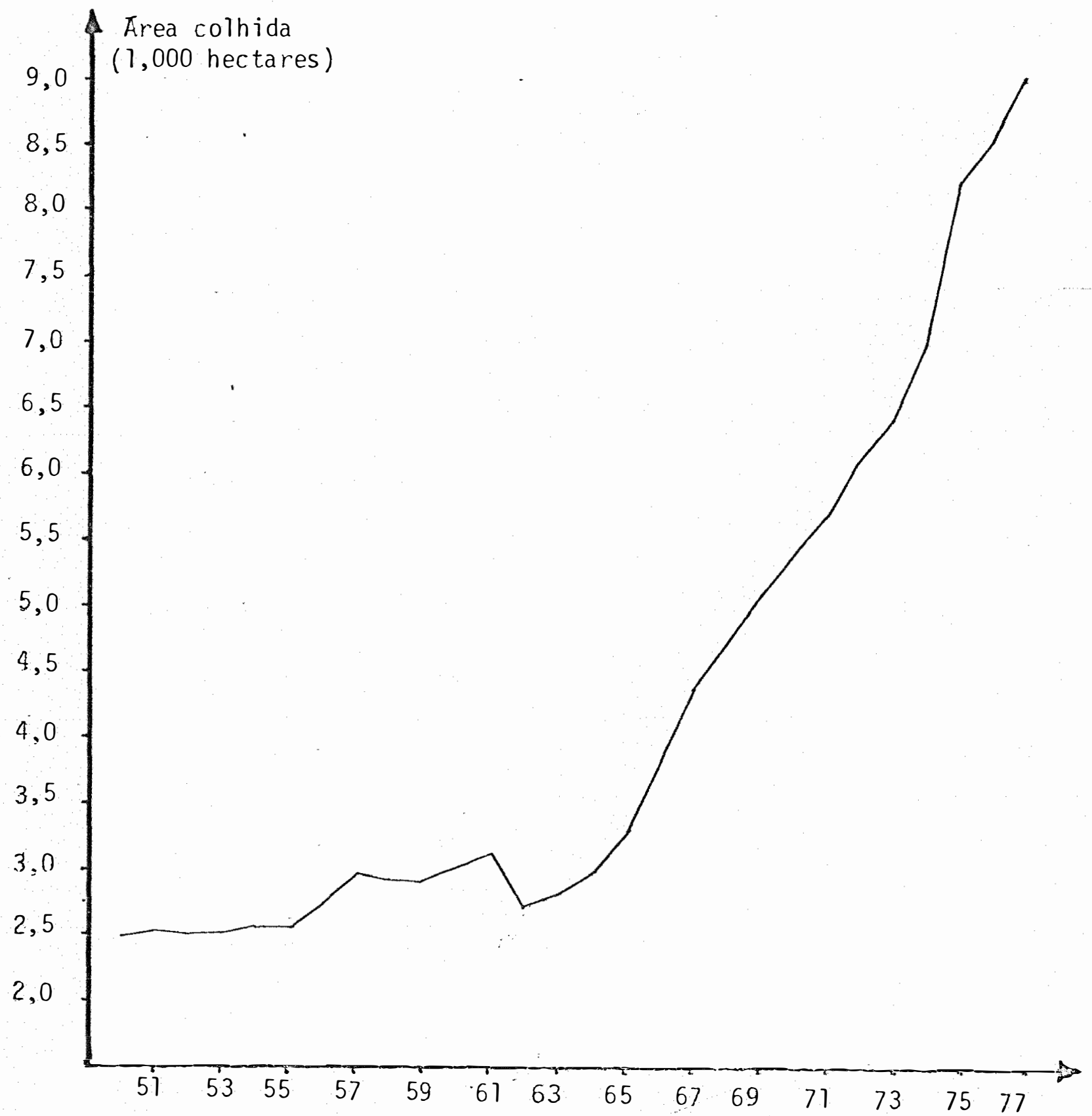


19.

Figura 8: Evolução da produção de laranja no Estado da Bahia, periodo 1950/1977

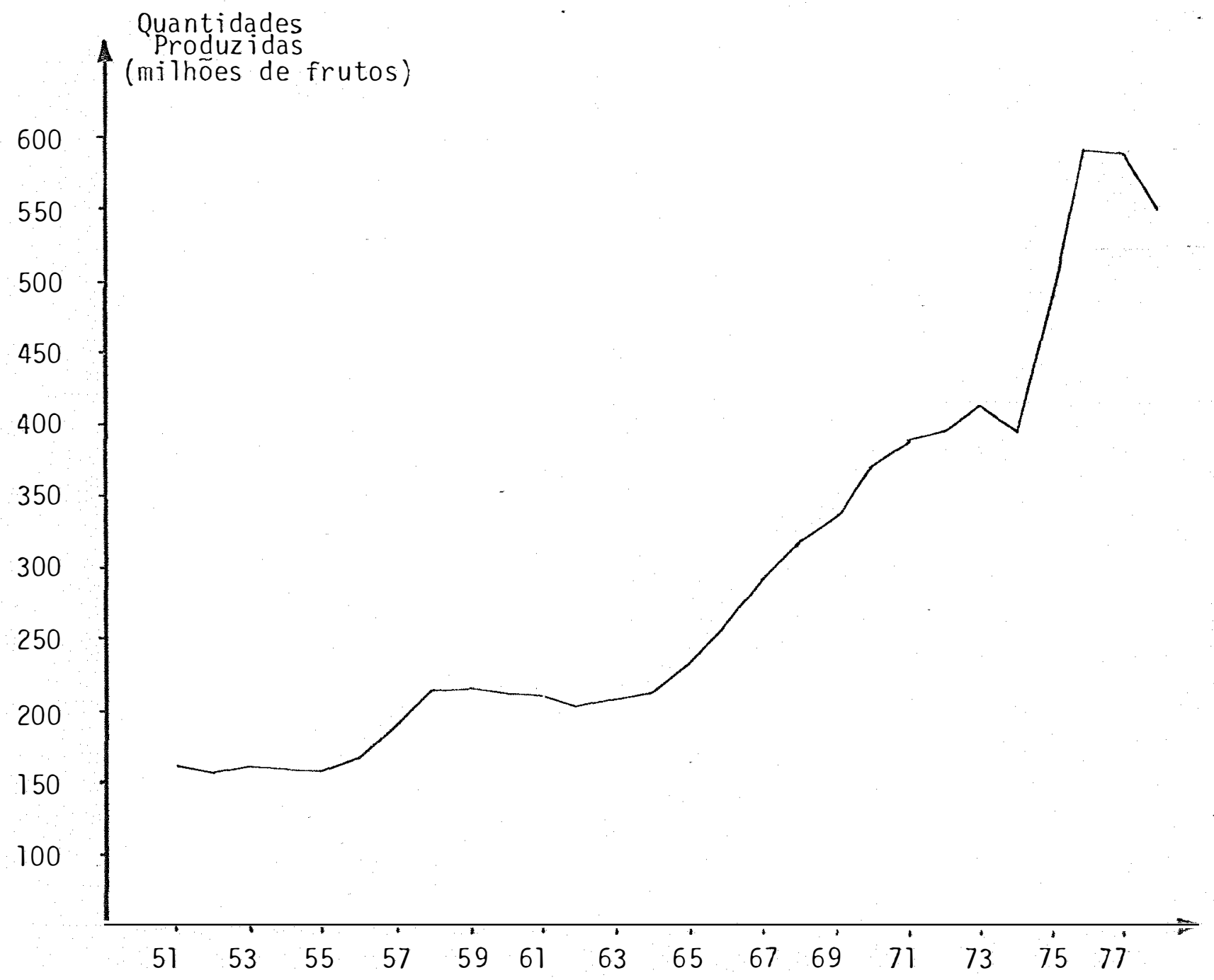


Figura 3: Evolução dos preços de laranja no Estado da Bahia, periodo 1947/1974

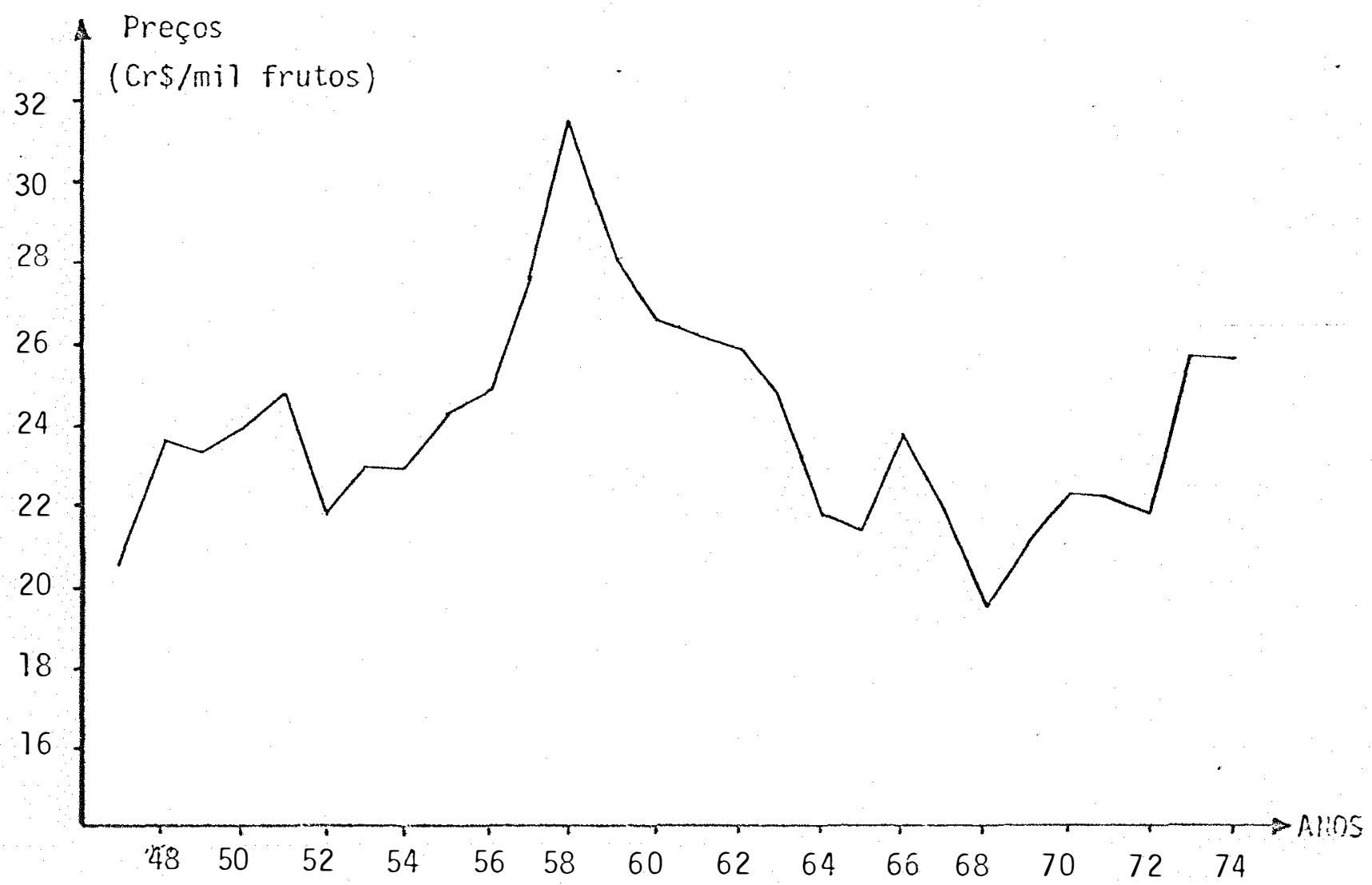

(*) Preços corrigidos pelo indice geral de preços - disponibilidade interna (média 1965/67 = 100) 
Almas, situada no Recóncavo Baiano, $41,3 \%$ dos citricultores re cebiam assistēncia financeira em 1969, conforme levantamento realizado por PASSOS et al (1970).

Um outro aspecto a ser considerado em relação à expansão da citricultura está relacionado com as transformações ocorridas no àmbito da lavoura fumageira na região Recóncavo Baiano. CARVALHo (1974) assinala que o ingresso de firmas es trangeiras na comercialização do fumo, exercendo ainda o con trole dos preços, desestimulou os produtores a permanecerem nesta atividade, fazendo com que grande parte deles passasem a se dedicar à citricultura.

Até o final dos 60 anos predominavam nos pomares a variedade 'Bahia', o que ocasionava uma concentração da pro dução em um período muito curto. Gradativamente, outras varie dades, principalmente 'Pera' e 'Baianinha', ampliaram bastante as suas participações na área total de citros. De acordo com estimativas de PASSOS et al (1970), a composição dos pomares em 1969 era de, aproximadamente, 60\% para a variedade 'Bahia', 29\% para a variedade 'Pera' e $11 \%$ para outras variedades. Mais re centemente, de acordo com PASSOS et al (1978), a distribuição dos pomares foi estimada em $40 \%$ para as variedades 'Bahia' e 'Baianinha', $50 \%$ para a variedade 'Pera' e 10\% para outras va riedades.

A introdução das variedades 'Pera' e 'Baianinha,' apesar de ampliar um pouco o período de safra, não permitiu uma significativa redução na flutuação dos preços durante o ano. 
Is to porque estas variedades apresentam ciclos anuais de produ ção parecidos com o da variedade 'Bahia'. A figura 4 ilustra bem este aspecto: como pode ser observado, os picos de produção de laranjas 'Bahia' e 'Pera' ocorrem entre os meses de junho e agosto, respectivamente, caindo logo em seguida. Como a laran já e um produto altamente perecível, as possibilidades de re duzir as flutuações de preços ficam quase que restritas à uti lização de uma composição do pomar com variedades precoces, tar dias e semi-precoces de modo a permitir aumentar a oferta nos períodos de escassez atual ou, ainda, reduzir a produção nos períodos de excesso de oferta.

A quase totalidade da produção de laranjas do Estado da Bahia destina-se ao consumo interno "in natura", com eventuais exportações para outros estados, principalmente da região Nordeste, porēm em pequenas quantidades. A produção tem se mostrado insuficiente para atender à demanda interna, apre sentando o Estado um saldo desfavorāvel nas trocas interestidu ais. A Tabela 7 apresenta as quantidades exportadas e importa das de laranja, por destino e procedéncia, estimadas pelo MI NISTERIO DA AGRICULTURA (1978).

De 1971 a 1977, a produção de Iaranjas no Estado da Bahia apresentou uma firme tendéncia expansionista, com in crementos médios anuais da ordem de $8 \%$. Merece destaque o fato de que a expansão da produção tem se verificado pela ampliação da fronteira agrícola jā que os rendimentos físicos por hecta re tēm se mantido mais ou menos constantes, com pequenas varia 
Figura 4: Flutuações mensais das quantidades de laranja "Bahia" e "Pera" comercializadas na CEASA/BA, periodo $1977 / 78$

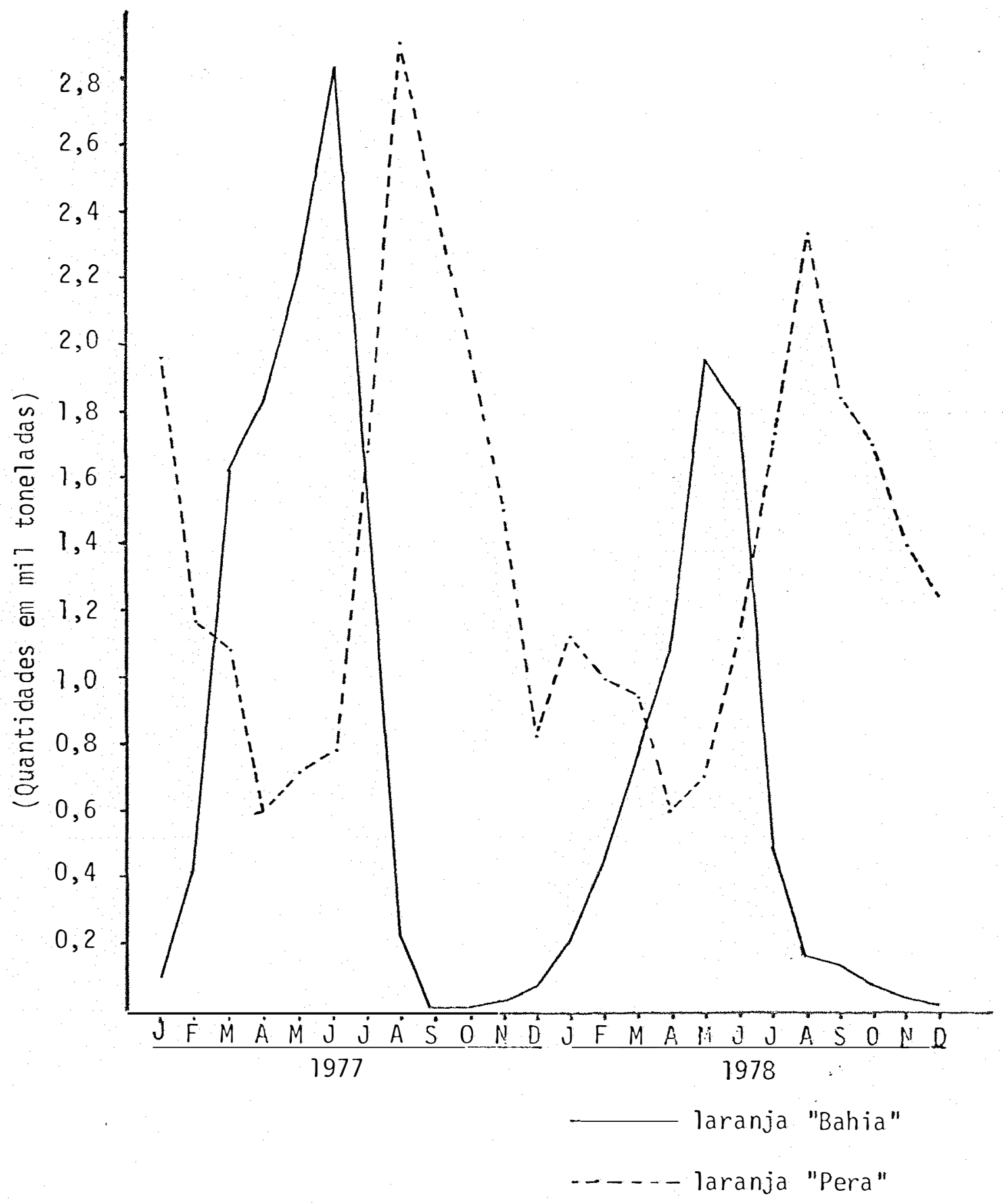

FONTE DOS DADOS: Divisão Técnica da CEASA/Bahia 
Tabela 7 - Importação e Exportação de laranja pelo Estado da Bahia, 1977

\begin{tabular}{lcc}
\hline Procedencia elou & $\begin{array}{c}\text { Quantidades } \\
\text { Importadas (ton) }\end{array}$ & $\begin{array}{c}\text { Quantidades } \\
\text { Exportadas (ton) }\end{array}$ \\
\hline Piauí & - & 445,5 \\
Cearā & - & $1.765,0$ \\
Rio Grande do Norte & - & 26,8 \\
Paraíba & - & 171,5 \\
Pernambuco & 2,4 & 564,2 \\
Alagoas & - & 38,4 \\
Sergipe & $5.049,7$ & 128,5 \\
Rio de Janeiro & - & 50,1 \\
São Paulo & 270,1 & - \\
Outros estados & 20,0 & - \\
\hline
\end{tabular}

OBS.: Os dados referem-se às quantidades comercializadas atra vés das CEASAS.

Fonte: BRASIL. Ministério da Agricultura (1978) 
ções devidas,principalmente, a fatores climáticos. Contudo, uma avaliação mais cuidadosa do rendimento da cultura fica, prejü dicada pelo desconhecimento da composição de idade do estoque das árvores. Isto porque o rendimento é estimado em função da produção e da área colhida totais incluindo os pomares mais novos (com 2 a 3 anos) que apresentam produção irrisória. Como. a taxa de incremento na área apresenta tendéncia crescente, o rendimento assim calculado é, então, subestimado.

O consumo de laranjas no Estado da Bahia é baixo quando comparado com os observados em São Paulo e Rio de Jane ro. Possivelmente, o baixo consumo de laranjas no Estado da Bahia possa ser explicado pela excassez do produto durante uma parte do ano, causada pelo alto percentual de áreas cultivadas com variedades que apresentam ciclos iguais de produção. A re dução da oferta em determinadas épocas do ano eleva o preço da fruta, restringindo o consumo. Ademais, o baixo nivel de renda no Estado da Bahia, comparativamente ao da região Sudeste, deve explicar, tambēm, a diferença no consumo "per capita" entre a Bahia e os Estados de São Paulo e Rio de Janeiro.

Em relação aos preços, a Tabela 8 apresenta os preços médios de laranja, a nível de produtor, nos estados da Bahia e São Paulo, para o período 1971/1976. Comparando-se os preços para os dois estados, verifica-se que os produtores do Estado da Bahia são melhor remunerados do que os citricultores paulistas. 


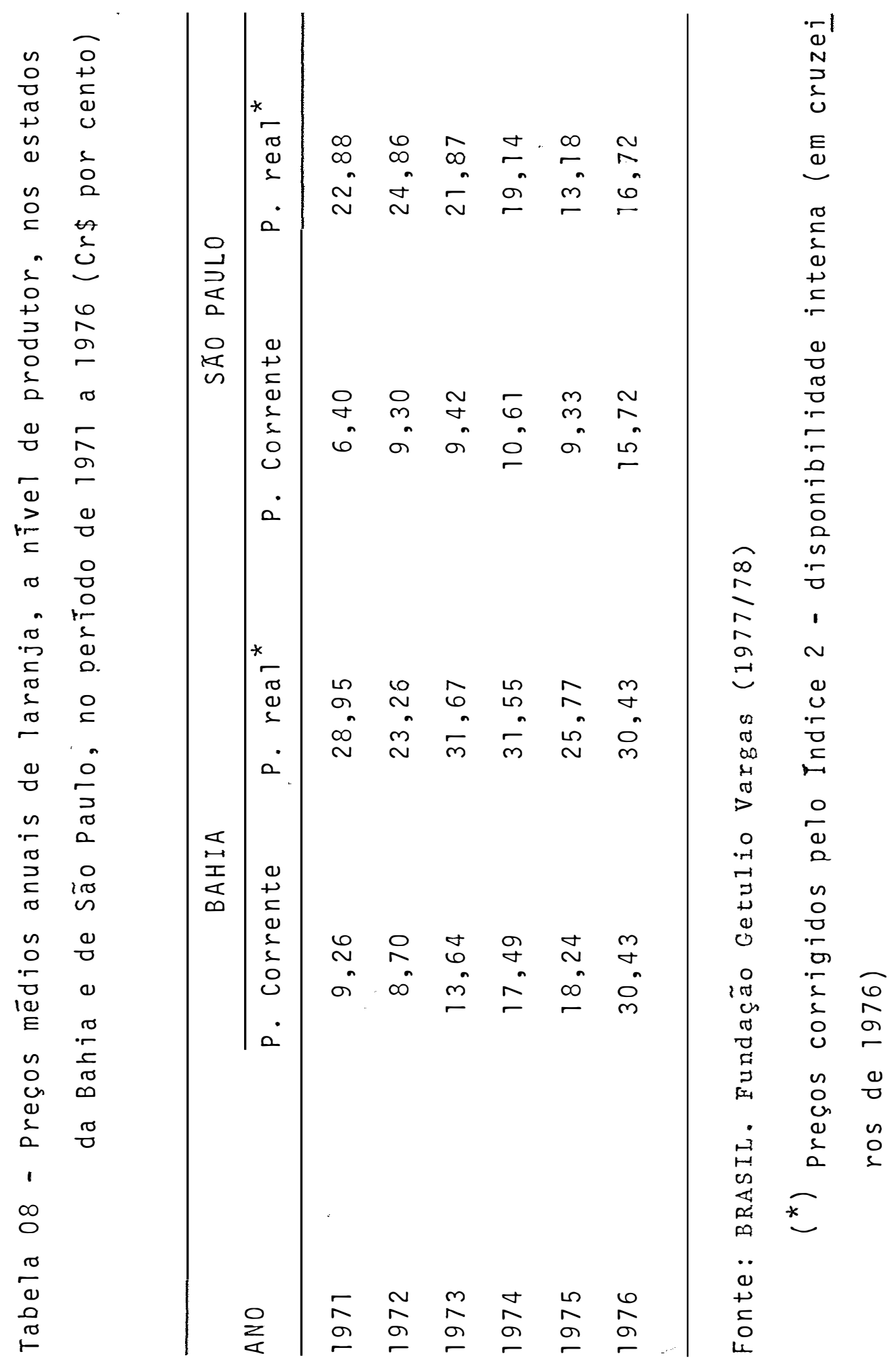


1.4. Hipōteses e pressuposições

As hipóteses a serem testadas no presente traba Tho podem ser descritas do seguinte modo:

- a citricultura baiana reage a mudança de pre ços, apresentando respostas diferentes para curto e longo pra zos. Espera-se que no curto prazo a resposta da ārea a varia ções nos preços sejam menos intensas que no longo prazo.

- em relação à demanda, espera-se que variações nos preços da laranja e nos preços de outras frutas afetem as quantidades adquiridas pelos atacadistas. Espera-se, ainda, efeito negativo para preço da 7 aranja.

A pressuposição básica dos modelos utilizados $\bar{e}$ de que o equilibrio de mercado é do tipo "Teia de aranha", de modo que a oferta corrente é afetada por preços defasados en quanto do lado da demanda as quantidades respondem a variações dos preços correntes. Pressupõe-se, ainda, que a formação de expectativas leva em conta que os preços passados e presentes perdurarão no futuro (expectativas estáticas). 
2. OBJETIVOS

Este estudo tem os seguintes objetivos gerais:

a. formular, analisar e descrever um modelo eco nométrico que permita melhor conhecimento de relações que determinaram a expansão da citricultura baiana.

b. formular, analisar e descrever um modelo eco nométrico de demanda de laranja a nível de atacado para o Esta do da Bahia.

Especificamente, são os seguintes os objetivos da pesquisa:

a.1. identificar as variáveis que afetam a ārea colhida de Iaranja no Estado da Bahia;

a.2. estimar as elasticidades-preço e elasticida 
des cruzadas da oferta no curto e longo prazos;

b.1. identificar as variáveis que afetam a deman da de laranjas a nível de atacado no Estado da Bahia;

b.2. estimar a elasticidade-preço da demanda;

b.3. identificar as frutas que competem com a. laranja no mercado e de que modo afetam a demanda por laranjas.

0 conhecimento a respeito dos efeitos de mudanças de preços na produção e comercialização de produtos agrícolas são de grande relevāncia no estabelecimento de politicas e pro gramas governamentais, principalmente em paises predominante mente agrícolas onde os problemas referentes a estabilização de preço e renda estão diretamente relacionados com as elasticida des de oferta e demanda de um grande número de produtos.

Os estudos que objetivam estimar elasticidades de oferta e demanda são, assim, de grande validade como instru mentos que ajudam na orientação da política agrícola como, tam bém, na avaliação dos custos e benefícios dos programas gover namentais.

As anālises de oferta e demanda consideram ape nas as laranjas. A exclusão de outras frutas cítricas como $1 \underline{i}$ mões, limas e tangerinas deveu-se à não disponibilidade de da dos suficientes. Contudo, vale salientar que a participação des tas frutas no mercado citrícola do Estado da Bahia é pouco ex pressiva. 


\section{REVISAO DE LITERATURA}

Uma caracterìstica dos fenómenos económicos è a simultaneidade de fatos. Tal ocorre, por exemplo, nos casos em que a ofertae a demanda de um produto são determinadas simulta neamente. Nestes casos, e ainda mais quando os dados utilizados sào gerados por um modelo interdependente, è necessārio a utilização de equações simultāneas para a estimação de parâmetros. Contudo, quando se admite que o equilibrio de mercado é do tipo "teia de aranha" de modo que a oferta relaci ona quantidades correntes e preços defasados e a demanda relaciona quantidadese preços correntes, as equações podem, então, ser estimadas separadamente. 
0 processo de ajustamento da oferta às variações nos preços apresentam um maior grau de complexidade nas cultú ras perenes, como é o caso da laranja, do que nas culturas de ciclos curtos. Em parte, esta complexidade está relacionada ao período longo de tempo, às vezes de diversos anos, entre o in cio do investimento e a produção comercial e ainda pelo perío do extenso do fluxo de produção desde o início até a queda da capacidade produtiva das plantas. Considerando estes fatos, a especificação de um modelo de oferta para culturas perenes de ve permitir explicar tanto o processo de plantio como a erradi cação e a renovação de pomares e, também, considerar explīcita mente o espaço de tempo entre o investimento inicial e a produ ção, bem como os efeitos de variāveis que interagem no proces so de decisão dos produtores.

Para o Brasil, e especificamente para a cultura da laranja, a formulação de um modelo que explique as relações acima mencionadas fica limitada pela não disponibilidade de da dos estatísticos sobre plantios anuais, erradicaçãode pomares, distribuição de idade das plantas e quantidade de plantas por unidade de ārea.

Preferentemente, os pesquisadores têm utilizado modelos de oferta com defasagens distribuítas para estimar as elasticidades de curto e longo prazos.

Entende-se como defasagens distribuitas ao fato de uma causa económica produzir seus efeitos depois que se pas sa algum tempo, de modo que este efeito não se faz sentir de 
uma sō vez, mas é distribuĩdo em um determinado período.

Em relação à oferta, a ocorrencia de retardamen tos distribuídos tem as seguintes explicações: a) dada uma va riação nos preços, as quantidades ofertadas se ajustam aos no vos preços decorrido al gum tempo necessārio às modificações nos ativos fixos das firmas; b) os produtores levam algum tempo pa ra reconhecer que os preços mudaram de forma permanente e para ajustarem suas espectativas com base nesta mudança; c) o proces so de produção requer tempo, muitas vezes vārios anos, atē que se efetive em produto.

NERLOVE (1958) indica vārios modos de se estimar defasagens distribữdas: a) não pressupondo uma forma de dis tribuição das defasagens; b) pressupondo uma forma geral para a distribuição e estimar os parāmetros que definem a distribui ção exata e, c) desenvolvendo um modelo dināmico explícito de comportamento do produtor ou consumidor que implique uma dis tribuição de defasagens apenas incidental. 0 grau de autocorre lação em muitas sēries temporais nem sempre torna possīvel a utilização da primeira aproximação. No segundo caso, a pressu posição de uma forma de distribuição das defasagens è arbïtri ria. A terceira aproximação permite uma interpretação direta da distribuição das defasagens em termos de diferença entre as elasticidades de curto-prazo e de longo-prazo.

FRENCH et al (1962), elaboraram um modelo de resposta de 1 imão para os Estados Unidos, pressupondo que as decisões dos produtores são baseadas nos preços correntes, pre 
ços passado e nos retornos esperados. O modelo desenvolvido en volve uma equação para área plantada anualmente e outra para área removida. A primeira equação é formulada de modo que os novos plantios dependem da expectativa de lucros no longo-pra zo e da distribuição de idade das ārvores jā existentes. Ālge bricamente, a equação tem a seguinte forma:

$$
\text { (3.1.) } \frac{N_{t}}{B_{t-1}}=b_{0}+b_{1} \pi_{t-1}^{*}+b_{2} \frac{A_{t-1}}{B_{t-1}}+v_{t-1}
$$

onde:

$$
\begin{aligned}
& N_{t} \text { - ärea plantada no ano } t \\
& B \quad \text { - área em produção } \\
& \pi^{*} \text { - expectativa de lucro no longo-prazo } \\
& A \quad \text { - área com ārvores em produção com mais de } \\
& \quad 25 \text { anos de idade. } \\
& 0 \text { termo }\left(A_{t-1} / B_{t-1}\right) \text { considera o efeitono plantio }
\end{aligned}
$$

do período $t$ das remoções efetuadas no perīodo $t-1$. A especta tiva de lucro $\left(\pi^{*}\right)$ é dada por uma mëdia dos lucros nos ūltimos cinco anos, ou seja:

$$
\bar{\pi}_{t-1}=\frac{1}{5} \sum_{i=t-1}^{t-5}
$$

onde $0 \pi \vec{e}$ o retorno liquido real no ano $i(i=t-1, \ldots, t-5)$

A equạção para ärea removida foi expressa do se guinte modo: 
$(3.3$.

$$
\frac{R_{t}}{B_{t}}=a_{0}+a_{1} \pi_{t}^{\prime}+a_{2} \frac{A_{t}}{B_{t}}+\frac{K_{t}}{B_{t}}+u_{t}
$$

onde:

$R_{t}$ - ärea removida

$B_{t}$ - ārea em produção

$\pi_{t}{ }^{\prime}$ - lucro corrente esperado (curto-prazo)

At - proporção de ārea removida com mais de 25 $B_{t}$ anos de idade.

$\underline{K_{t}}$ - proporção de área removida devido à expan $\mathrm{B}_{t}$ são urbana.

Os parãmetros das equações (3.1.) e (3.2.) foram estimados por mínimos quadrados aplicados a série de dados re ferente ao período 1947/1960. Para a equação de novos plantios, as estimativas foram significantes para o parāmetrodavariāvel expectativa de lucro e não significativa para o termo $A_{t-1} / B_{t-1}$. Em relação à equação para ārea removida, todos os parāmetros resultaram não significantes.

BATEMAN (1970), revisa vārios trabalhos relacio nados a funções de oferta para culturas perenes e sugere mode los gerais que podem ser aplicados na anālise dos fatores que motivam os produtores a plantar e no estudo das relações entre ārea plantada e produção.

No Brasil, ainda são escassos os trabalhos de es timação de oferta e demanda para culturas perenes.

NAMEKATA (1977) comparou diversos modelos de ofer 
ta agregada de citros, para o Estado de São Paulo, utilizando série temporal de dados para o período 1948/1975. Os modelos para resposta da ārea e do rendimento com defasagens distribui das e os modelos de equações simultāneas apresentaram melhores ajustamentos que os demais utilizados. Os resultados indicaram retardamento de 3 anos como o melhor para as variáveis indepen dentes indicadoras de preço do produto, preço de fertilizantes e ārea, para as equaçoes explicativas de ārea colhidadecitros.

NORONHA et al (1978) testaram dois modelos de ajustamento de oferta e demanda de Iaranja no Estado de São Pau 10. No modelo de equações simultāneas, estimado pelo método de mínimos quadrados de dois estāgios, as elasticidades-preço fo ram de 0,85 e $-0,24$ para a oferta e demanda, respectivamente e, quanto à variável renda, apresentou uma elasticidade de 0,55 ; as elasticidades cruzadas para mamão, banana e abacate $(0,108$, $-0,057$ e 0,070 , respectivamente) foram estatisticamente insig nificantes, enquanto para maçãs argentinas foi de 0,22 (sig nificante a $5 \%$ ) denotando existir baixissimo poder de competi ção entre estas frutas e a laranja; do lado da oferta, a variā vel preço de mudas apresentou uma elasticidade de $-0,516$, mos trando que aumentos no preço deste insumo refletem-se em redu ções na quantidade ofertada de Iaranja.

Um dos problemas encontrados com a estimação de modelos de oferta e de demanda a partir de dados de séries tem porais está relacionado com a ocorréncia de autocorrelação, o que leva a produzir estimativas viesadas das elasticidades quan do se utiliza o método de mīnimos quadrädos ordinārios. 
COCHRAN et al (1949) relacionam tres situações em que aparece autocorrelação nos residuos: 1) quando as séries de dados são autocorrelacionadas e a forma da função ē escolhida incorretamente; 2) quando se omite do modelo variáveis que são geralmente autocorrelacionadas e, 3) quando ocorre erros de me dição dos dados, frequentemente autocorrelacionados.

Em relação aos vieses provocados pela presença de autocorrelaçãó em modelos de defasagens distribuídas, FUELLER et al (1961) fazem as seguintes observações:a) resíduos positi vamente autocorrelacionados frequentemente resultam em subesti mação da elasticidade de ajustamento e da elasticidade-preço de curto prazo e sobrestimação da elasticidade-preço de longo-prá zo; b) autocorrelação negativa resulta em sobrestimação da elas ticidade de ajustamento e da elasticidade-preço de curto-prazo.

GRILLICHES (1967) afirma que, na maioria dos ca sos, pode-se reduzir a autocorrelaçãodos resîduos pela adição, na regressão, da variável dependente defasada no segundo membro da equação. Mesmo com problemas de especificação, um modelo com defasagens distribuīdas pode produzir estimativas razoáveis des de que a correlação serial da verdadeira perturbação não resul te numa maior fração da variação da variável dependente. 
4. METODOLOGIA

\subsection{Modelo teórico}

Uma caracteristica dos modelos utilizados $\bar{e}$ a pressuposição de que a quantidade ofertada no perīodo $t$ depen de do preço no período $t-i$ e que estes preços afetarão a quan tidade ofertada e não a procura. Assim considerado, a oferta $\vec{e}$ determinada pelas quantidades correntes e preços defasados, e a demanda pelas quantidades e preços correntes.

\subsubsection{Equilîbrio dinâmico com ajustamento defasado.}

Uma característica da produção agrícola è que, geralmente, o ajustamento da produção aos preços dá-se após 
decorrido um certo período de tempo necessārio para que os plan nos de produção se efetivem em mercadorias produzidas. Deste modo, pode-se estabelecer a quantidade ofertada como função dos preços defasados, ou seja, dos preços considerados no momento de tomada de decisão sobre quanto produzir. Supondo, ainda, que a quantidade demandada é função do preço corrente, pode-se re presentar as funções de oferta e demanda do seguinte modo:
$(4.1 .1$.
$Q^{S}=a_{0}+a_{1} P_{t-i}$
(oferta)
$(4.1 .2$.
$Q^{d}=b_{0}+b_{1} p_{t}$
(demanda)

Pressupondo que os produtores não formam esto ques e que não hā demanda insatisfeita dos consumidores, a qua n tidade ofertada será igual à quantidade demandada, ou seja:
$(4.1 .3)$

$$
Q^{S}-Q^{d}=0
$$

Substituindo-se (4.1.1.) e (4.1.2.) na relação (4.1.3.) e resolvendo para $P_{t}$, tem-se:

(4.1.4.) $\quad p_{t}=\frac{a_{0}-b_{0}}{b_{1}}+\frac{a_{1}}{b_{1}} p_{t-i}$

A expressão (4.1.4.) è uma equação a diferenças de primeiro grau cuja solução, admitindo-se que a condição in $\underline{i}$ cial seja dada por $P=P_{0}$ quanto $t=0$, $\bar{e}$ dada por:
$(4.1 .5$.
$P_{t}=\left(P_{0}-\frac{a_{0}-b_{0}}{b_{1}-a_{1}}\right)\left(\frac{a_{1}}{b_{1}}\right)^{t}+\frac{a_{0}-b_{0}}{b_{1}-a_{1}}$

A relação (4.1.5.) descreve a trajetória do preço 
em função do tempo e permite obter-se as condições de convergen cia até um preço de equilíbrio $\left(P_{e}=\frac{\left.a_{0}-b_{o_{-}}\right)}{b_{1}-a_{1}}\right.$. Se não houver variaçö́es de preço de um período parâ outro $\left(P_{t}=P_{t-i}\right)$ me m cado estará em equilíbrio dinâmico. O mercado será dinamicamen te estável se $P_{t} \rightarrow P_{e}$ quando $t \rightarrow \infty$. A condição de estabilidade depende do valor absoluto do coeficiente $a_{1} / b_{1}$ que mede a rela ção entre as inclinações das funções de oferta e demanda: se $-1<a_{1} / b_{1}<1$ (valor absoluto do coeficiente $a_{1} / b_{1}$ for menor que a unidade), o mercado é dinamicamente estável; se $\left|a_{3} / b_{1}\right| \geq 1,0$ mercado é dinamicamente instāvel.

A trajetōria descrita pelo preço em função do tem po pode produzir um tipo de estrutura conhecida como "teia de aranha". A Figura 8 ilustra a trajetória para um caso em que o preço converge para o nível de equilíbrio indicado pela inter seção das curvas de oferta e de demanda.

Figura 8 - Estabilidade dināmica em mercado de um produto

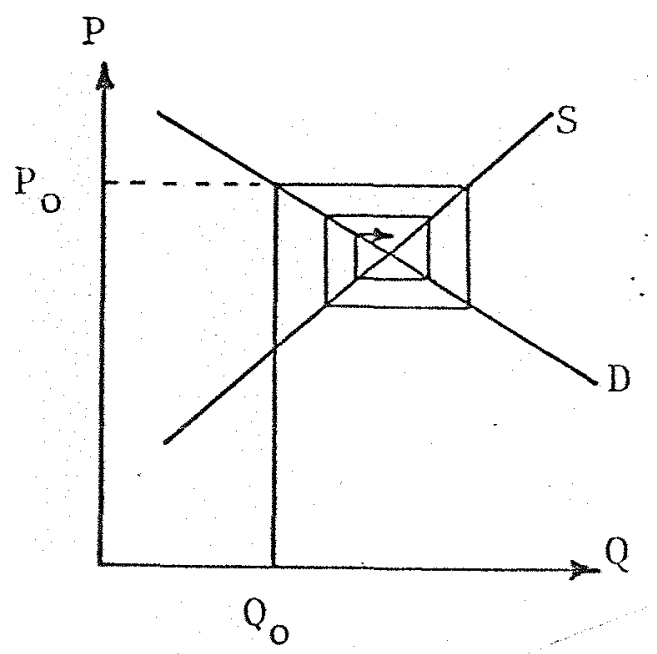




\subsection{Modelo econométrico}

\subsubsection{Modelo de resposta da área com defasagens.}

0 modelo básico a dotado para estimação de respos ta da área a variáveis econōmicas segue a formulação de NERLOVE (1958), dada a pressuposição de que os citricultores ajustam a ārea colhida do ano $t-3$ para o ano $t$ em proporção à diferença entre a área colhida observada no ano t-3 e a área esperada no ano $t$.

Sendo $Y_{t}^{*}$ a ārea que os produtores esperam colher logo que se tenha passado o tempo necessário para a realocação dos fatores de produção, uma função de resposta para o "longo prazo pode ser especificada do seguinte modo:

$$
\text { (4.2.1.) } \quad \gamma_{t}^{*}=a_{0}+a_{1} p_{t-3}+u_{t}
$$

onde $P_{t-3}$ é o preço de laranja defasado e $u_{t} \bar{e}$ o erro.

0 caráter dinámico do modelo é dado pela defasa gem de tempo em que a ārea $\left(Y_{t}^{*}\right)$ responde a mudança na: variāvel preço.

A pressuposição de que o ajustamento ocorrido no período $t$, em relação ao perīodo $t-3$ é proporcional ao ajustą mento total desejado no longo prazo, é dada pela seguinte rela ção:

(4.2.2.) $\quad Y_{t}-Y_{t-3}=B\left(Y_{t}^{*}-Y_{t-3}\right)$ 
onde $0<\beta \leq 1$.

0 termo $\beta$, da relação (4.2.2.) é chamado de elas ticidade de ajustamento ou coeficiente de ajustamento, conforme $Y_{t,} Y_{t}^{*}$ e $Y_{t-3}$ sejam expressos em logaritimos ou nos valores ob servados destas variáveis. O coeficiente ou elasticidade de ajustamento exprime a velocidade com que a oferta atual se ajus ta à oferta esperada no longo prazo.

\section{A equação $(4.2 .1$.$) apresenta uma variāvel \left(Y_{t}^{*}\right)$} que não é diretamente observável, impedindo que se estime as elasticidades de longo prazo de forma direta. Pela substitui ção de (4.2.2.) em (4.2.1.) e explicitando para $Y_{t}$, tem-se:

(4.2.3.) $\quad Y_{t}=\beta a_{0}+\beta a_{1} P_{t-3}+(1-\beta) Y_{t-3}+\beta u_{t}$ que não deve ser considerado como uma função de oferta mas sim uma relação entre variáveis observāveis.

obtidas as estimativas dos parämetros da relação (4.2.3.) pode-se, então, obter as estimativas dos coeficientes da função de oferta de longo prazo dividindo-se às estimativas de $\beta a_{0}$ e $\beta a_{1}$ pela estimativa de $1-(1-\beta)$.

0 coeficiente ou elasticidade de ajustamento, $\beta$, pode ainda ser utilizado para fornecer o tempo necessārio para que a área corrente se iguale a uma propoirção a da área de lon go prazo, através da seguinte fórmula:
$(4.2 .4$.
$(1-\beta)^{t}=1-\alpha$ 
A equação (4.2.4.) é obtida resolvendo-se a equa ção de diferenças representada por (4.2.2.) (NERLOVE etal, 1958) e (PASTORE, 1973).

\subsubsection{Modelos de demanda}

A anālise da demanda foi efetuada considerando se dois modelos básicos.

O primeiro modelo utilizado para estimativa das elasticidades de demanda segue a mesma formulação feita para a oferta. Pressupõe-se que a diferença nas quantidades adquiri das entre o período t-l e o período t é uma proporção do ajus tamento total desejado no longo prazo. Na sua forma estrutural o modelo pode ser representado pelas seguintes equações:
$(4.2 .5$.
$Q_{t}^{*}=b_{0}+b_{1} P_{t}+z_{t}$
$(4.2 .6$.
$Q_{t}-Q_{t-1}=\lambda\left(Q_{t}^{*}-Q_{t-1}\right)$

Das equações estruturais representadas por (4.2.5.) e (4.2.6.) obtem-se a forma reduzida da qual são esti mados os parāmetros através de minimos quadrados ordinários:

$(4.2 .7$.

$$
Q_{t}=\lambda b_{0}+\lambda b_{1} P_{t}+(1-\lambda) Q_{t-1}+\lambda z_{t}
$$

onde $\lambda \bar{e}$ o coeficiente ou elasticidade de ajustamento, $\lambda b_{i}$ os parāmetros da equação de longo prazo e $Q_{t} \bar{e}$ a quantidade deman . dada.

A formulação de um modelo de expectativas estáti 
cas para a demanda de laranja a nivel de atacado baseia-se na pressuposição de que, dada uma mudança nos preços da laranja, os atacadistas não revisam de imediato seus planos de compra até que se certifiquem de que as mudánças ocorridos persistirão no futuro. A razão para este tipo de comportamento do atacadis ta pode ser explicada pela necessidade de ampliação ou redução dos investimentos em equipamento de comercialização (galpões, transporte, etc.). Supondo-se, por exemplo, que ocorra uma que da brusca no preço da laranja, as mudanças nos planos de com pra, no sentido de aumentar as aquisições (mudança de expecta tiva) só se efetivarão na medida em que seja observado que o novo preço serā permanente.

0 segundo modelo foi formulado de modo que a quan tidade de laranja demandada ao nível de atacado é função do pre ço corrente da laranja. Algebricamente, a equação explicativa da demanda tem a seguinte forma:

$$
Q_{t}=b_{0}+b_{1} P_{t}+u_{t}
$$

onde $Q_{t} \bar{e}$ a quantidade demandada no período $t, P_{t} \bar{e} o$ preço corrente da laranja, $b_{0} e b_{1}$ são parāmetros a serem estimados e $u_{t}$ é o êrro. Se $Q_{t}$ e $P_{t}$ são medidos em logaritimos, $b_{1} \bar{e} a$ prōpria elasticidade-preço de curto-prazo da demanda.

\subsection{Definição das variāveis e dados utilizados}

os critērios para eleição das variāveis explica tivas de oferta e demanda de laranja no Estado da Bahia foram 
estabelecidos com base no conhecimento prévio sobre o processo de produção e comercialização, obtido de diversas fontes de in formação, tais como produtores, atacadistas, extensionistas, técnicos da CEASA/Bahia e pesquisadöres.

Contudo, algumas dificuldades apareceram na fase pós-seleção das variáveis, principalmente no que se refere à disponibilidade de dados. Em rélação à oferta, sentiu-se a ne cessidade de inclusão na equação de variáveis representativas de mudança tecnológica, preço de mudas cîtricas, crédito rural e assistência técnica, para as quais não foram encontrados da dos disponíveis. Do lado da demanda, a principal limitação re feriu-se à exclusão de variável representativa da renda da po pulação.

Em relação à oferta, as variāveis incluĩdas na anālise foram definidas do seguinte modo:

A - ärea colhida de laranja no ano $t$

A $_{\text {t- }}$ - ārea colhida de laranja, defasada 3 anos

$P_{t-3}^{L}$ - preço real da laranja, defasado 3 anos

$P_{t-3}^{F}$ - preço real do fumo defasado 3 anos

D - variāvel "dummy" para intercepto e incli nação. $D=1$ de 1950. a 1965 e $D=0$ de 1966 a 1977.

Z - variável indicadora de tendẽncia $(Z=1$, $2, \ldots, 28)$.

A variāvel preço do fumo defasada 3 anos $\left(P_{t-3}^{F}\right)$, 
incluída no modelo, tem como finalidade captar mudanças área colhida de laranja causadas por variação no preço da prín cipal cultura que compete pela ārea nas regiões citrícolas.

A inclusão da variável "dummy" para intercepto e inclinação foi feita de modo a permitir uma anālise mais acura da das mudanças verificadas na resposta da ārea às variações nos preços de laranja em dois periodos característicos da ci tricultura baiana: o período de 1947 a 1965 caracterizado pela quase estagnação do crescimento da ārea, e o período de 1966 a 1977 quando a expansão da ārea deu-se a taxas crescentes.

A variável tendencia ( $Z$ ) incluî́da no modelo teve como objetivo reduzir o viés de especificação sobre o coeficí ente da variável ärea defasada $\left(A_{t-3}\right)$ provocado pela omissão de variāveis que explicam a tendéncia crescente da área colhi da .

Do lado da demanda, as variáveis foram definidas como se segue:

$$
\begin{aligned}
& \text { Q - quantidade de laranjas 'Bahia' e 'Pera' } \\
& \bigcap_{t-1} \text { - quantidade de laranja 'Bahia' e 'Pera' }
\end{aligned}
$$


$P_{t}^{B}$ - preço real de banana, a nível de atacado;

$P_{t}^{A}$ - preço real de abacaxi, a nível de atacado;

Do - variāvel "dummy".para captar deslocamentos da demanda devido a mudança de estação.

$D_{0}=0$ no inverno (abril a novembro)

$D_{0}=1$ no verão (dezembro a março);

$D_{1}$ - variāvel "dummy" para captar deslocamentos da demanda devido a preferéncia por laran ja 'Bahia'. $D_{1}=0$ quando predomina laran ja 'Pera' no mercado e $D_{1}=1$ quando predo mina a laranja 'Bahia';

W - variável indicadora de tendēncia $(W=1$, $2, \ldots, 43)$.

Os preços de laranja foram obtidos ponderando-se os preços das variedades 'Bahia' e 'Pera' pelas respectivas quantidades comercializadas.

Foram util izados dados de séries temporais anuais para as estimativas de oferta e mensais para a demanda. A prin cípio, pretendeu-se utilizar apenas as series anuais de preços e quantidades. Porém, a impossibilidade de adotar tal procedi mento decorreu da não disponibilidade de dados suficientes pa ra estimar o consumo aparente de laranja no periodo considera do para análise, principalmente no que se refereàsquantidades produzidas no Estado da Babia e exportadas para outras regiões. Os dados utilizados e respectivas fontes estão 
relacionados nos Apēndices 1 e 2 .

Todos os preços foram corrigidos pelo Indice Ge ral de Preços - Disponibilidade Interna, obtido de diversos nū meros da revista Conjuntura Económica, editada pela Fundação Getūio Vargas. 


\section{RESULTADOS E DISCUSSÕES}

5.1. Resposta da ārea com defasagens distribuĩdas.

Dentre os modelos de resposta da ārea testados, - que apresentou melhor ajustamento ao caso da laranja no Esta do da Bahia está apresentado na Tabela 9 e será o considerado para fins de anālise, tendo em vista o grau de explicação das variāveis independentes e a coerénciados sinais dos parāmetros estimados com a teoria econōmica. No Apēndice 3 são relaciona das outras equações alternativas testadas mas que não apresen taram bom ajustamento.

Em todas as equações escolhidas as variáveis fo ram medidas nos logaritimos, exceto as variāveis tendēncia ( $Z$ ) e "dummy" (D). 
Tabela 9 - Estimativa dos parámetros do modelo ajustado de res posta da área colhida de laranja, Estado da Bahia, período $1947 / 1977$.

Variāveis

Estimativa

Explicativas

dos parāmetros

Intercepto

2,7162

$(1,57)$

$P_{t-3}^{L}$

0,2452
$(1,03)$

$P_{t-3}^{F}$

$-0,0864$

$(-0,90)$

Z

$0,0158^{*}$

$(1,67)$

D

$D P_{t-3}^{L}$

$1,8755^{* *}$
$(1,97)$

$-0,6449^{* *}$

$(-2,18)$

$A_{t-3}$

$0,6408^{* * *}$

$(4,78)$

$\mathrm{F}$

$R^{2}$

$270,95^{* * *}$

d

0,98

1,7505

h

0,877

$T^{2}$

0,187

OBS.: Os nümeros entre parénteses referem-se aos valores de $t$ de Student. Os asteriscos indicam o nível de significân cia a $1 \%(* * *), 5 \%(* *)$ e $10 \%(*)$. d e $h$ e $T^{2}$ referem-s $\bar{e}$ aos valores dos testes de Durbin-Watson, de Durbin, e de Theil-Nagar para autocorrelação, respectivamente. 
Figura 5: Valores observados e estimados de ārea colnida de Taranja no Estado da Bahia, periodo 1950/77

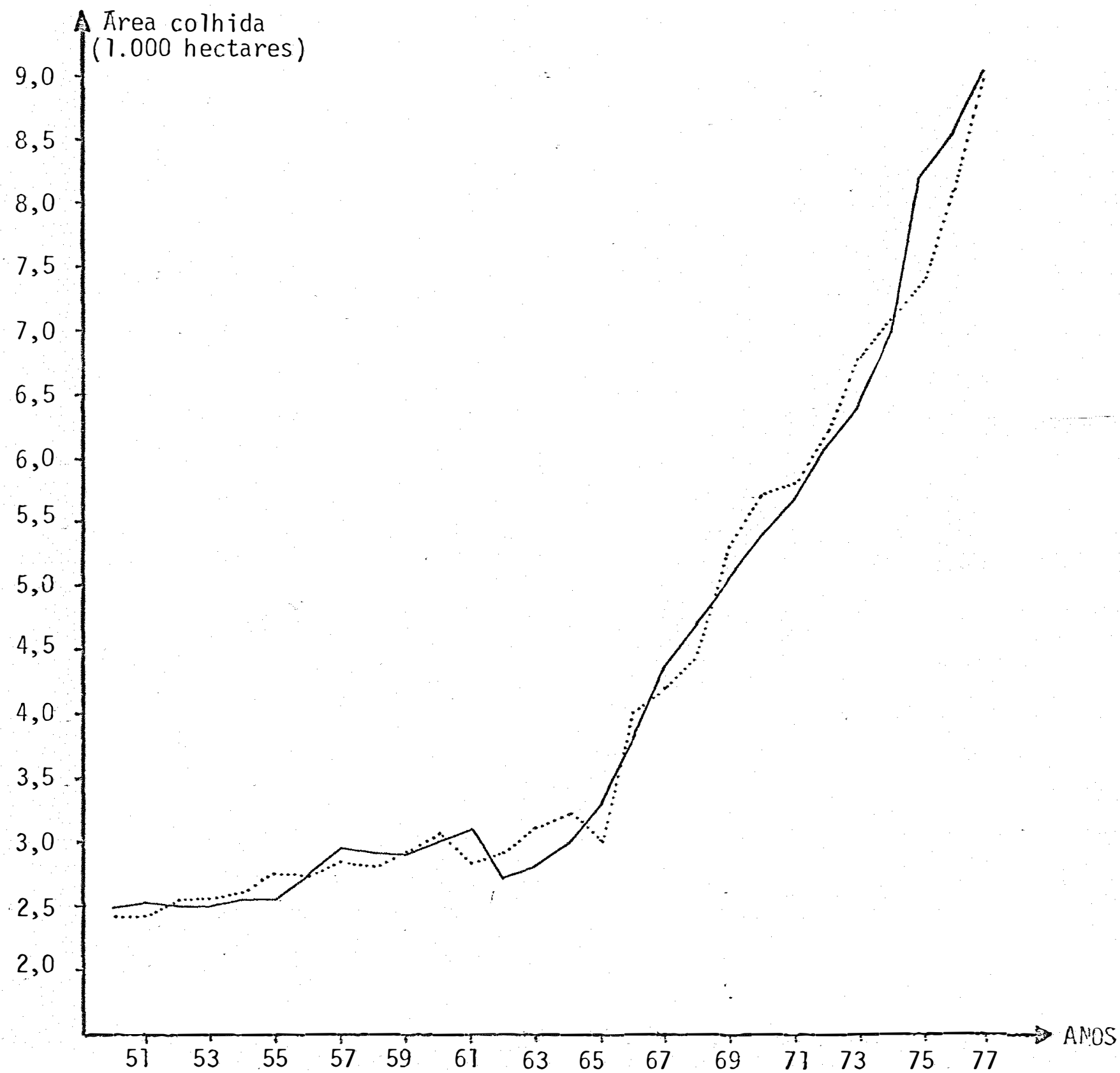

Observada 
0 coeficiente de determinação $\left(R^{2}\right)$ da equação se lecionada para análise foi da ordem de 0,98, demonstrando um al to grau de explicação das variáveis independentes incluîdas no modelo. A aplicação do teste $t$ de Student aos coeficientes de regressão parcial evidenciou a significância ao nível de $1 \%$ para a variāvel área defasada de 3 anos $\left(A_{t-3}\right)$, de $5 \%$ para as variāveis "dummy" para intercepto (D) e inclinação ( $D P_{t-3}$ ), e de $10 \%$ para a variável tendēncia ( $Z$ ). Os coeficientes das variá veis preço real de laranja defasado de 3 anos $\left(P_{t-3}^{L}\right)$ e preço real do fumo defasado de 3 anos $\left(P_{t-3}^{F}\right)$ não foram estatistica mente diferentes de zero embora os sinais estimados sejam coe rentes com a teoria econômica.

0 coeficiente de regressão parcial da variável tendência ( $Z$ ), da ordem de 0,02, significante a $10 \%$, indica que a expansão da área ao longo do tempo é afetada por variáveis que não foram incluídas explīcitamente na equação de regressão.

A inclusão de uma variável "dummy" (D) na equa ção teve como objetivo analisar o deslocamento da oferta ao lon go do tempo, partindo-se do conhecimento sobre o comportamento da área e do preço da laranja no período estudado. O coeficien te de regressão parcial da variāvel "dummy" para intercepto, igual a 1,875 indica que os coeficientes lineares para os pe ríodos 1950/1965 e 1966/1977 são distintos. O coeficiente esti mạdo em relação ao produto preço real da laranja $x$ "dummy" $\left(D P_{t-3}^{L}\right)$, da ordem de $-0,64$, mostra que a influēncia do preço na ārea colhida apresenta efeitos diferentes nos dois períodos 
considerados, evidenciando, ainda, respostanegativa para o perí do $1950 / 1965$, estatisticamente significante a $10 \%$. Contu do, tal fato pode ser explicado se for considerado o comporta mento do preço da laranja em relação ao preço do fumo. Isto po de ser observado atravēs da equação c do Apendice 3. Quando a variāvel preço é definida pela relação $\mathrm{P}_{t-3}^{\mathrm{L}} / \mathrm{P}_{\mathrm{t}-3}^{\mathrm{F}}$, a elasticida de assim estimada apresenta sinal positivo para os dois perío dos considerados. $(1950 / 65$ e 1966/77). Isto implica em que a queda no preço do fumo, sendo ma is que proporcional à queda no preço da laranja, eleva a relação $P_{t-3}^{L} / P_{t-3}^{F}$.

Em relação à variāvel área defasada de 3 anos $\left(A_{t-3}\right)$, o parāmetro estimado foi da ordem de 0,64 , altamente significativo, sugerindo que a expansão da ārea no longo prazo influencia a decisão de novos plantios.

Da equação estimada, apresentada na Tabela 9 , para se obter a função de resposta de longo prazo, torna-se ne cessārio apenas dividir os coeficientes por 1 menos o coefici ente da variāvel ārea defasada $\left(\hat{A}_{t-3}\right)$. Desse modo, tem-se:

$\log A_{t}^{*}=7,56+0,68 \log P_{t-3}^{L}-0,25 \log P_{t-3}^{F}+0,04 Z+5,22$ $D-1,80 \quad D \quad \log P_{t-3}^{L}$

Para o período 1950/1965, com $D=1$, a equação para o longo prazo é, então,

$$
\begin{aligned}
\log A_{t}^{*}= & 12,78-1,12-\log P_{t-3}^{L}-0,25 \log P_{t-3}^{F}+0,04 Z \\
& \text { Para o período } 1966 / 1977, \text { com } D=0, \text { tem-se: }
\end{aligned}
$$




$$
\log A_{t}^{*}=7,56+0,68 \log P_{t-3}^{L}-0,25 \log P_{t-3}^{F}+0,04 Z
$$

Considerando que as elasticidades de longo prazo dependem da proporção de dois coeficientes da regressão estima da, não se pode aplicar os mesmos testes de significāncia uti lizados na relação estimada, na equação de longo prazo. NERLOVE et al (1958) sugere que um teste de significância para as elas ticidades de longo prazo pode ser formulado. Contudo, "a prio ri", nada se pode dizer em relação à significāncia estatística das estimativas de longo prazo.

A elasticidade de ajustamento $(\beta)$, da ordem de 0,36 determina a velocidade com que a oferta de curto prazo se aproxima do seu equilibrio de 1.ongo prazo. Para que a ärea cor rente se iguale a $95 \%$ da área de longo prazo são necessārios, aproximadamente, 21 anos, pressupondo-se constāncia dos preços relativos e das demais variāveis.

Em relação à ocorrência de autocorrelação, a es tatistica d de Durbin-Watson é inconclusiva para autocorrelação positiva e não significativa para autocorrelação negativa, ao nível de $95 \%$ de probabilidade. As estatisticas $h$ de Durbin $(0,91)$ e $T^{2}$ de Theil-Nagar $(0,19)$ sugerem baixissima correla ção serial nos resíduos. Deve-se salientar, contudo, que o tes te de Durbin-watson não é apropriado para testar hipótese de ausência de autocorrelação em modelos onde a variāvel dependen te aparece defasada no segundo membro da equação e, em relação ao teste de Durbin (h), suas propriedades para o caso de peque 
nas amostras $(n<30)$ não são bem conhecidas como assinala JOHNSTON (1972).

\subsection{A demanda}

As equações I e II da Tabela 10 foram seleciona das para anālise dinámica da demanda de laranjas a nível de atacado, e as equações III e IV para anālise estātica, conside rando que, dentre as equações alternativas testadas, estas fo ram as que apresentaram melhores ajustamentos, tanto no que se refere ao grau de explicação, expresso pelos coeficientes de determinação $\left(R^{2}\right)$, quanto pelo alto grau de significáncia da maioria dos parāmetros estimados e, ainda, por não apresentarem problemas de autocorrelação. As estimativas foram obtidas a partir dos logaritimos das variáveis, exceto para as variáveis "dummy" $D_{0}$ e $D_{1}$. Desse modo, tem-se uma única medida das ela $\underline{s}$ ticidades, representada pelos próprios paràmetros estimados.

No Apēndice 3 são relacionadas outras equações alternativas estimadas, para fins de comparação.

A diferença bāsica entre as equações I e II da Tabela 10 consiste na definição das variāveis "dummy" $D_{0}$ e $D_{1}$ para intercepto, objetivando captar efeitos de deslocamentos das funções de demanda. Na equação I, a variāvel Do foi intro duzida afim de se observar possiveis deslocamentos da demanda causada por um maior consumo de laranjas no verão $\left(D_{0}=1\right.$ de dezembro a março) em relação ao inverno ( $D_{0}=0$ de abril a no 
vembro). Já na equação II, a variāvel di assume valor 1 quando predomina a variedade 'Bahia' no mercado e valor zero quando predomina a variedade 'Pera', admitindo-se que há uma preferên cia para o consumo de frutas menos àcidas, no caso, a laranja 'Bahia'.

A equação I, da Tabela 10 , apresenta um coefici ente de determinação $\left(R^{2}\right)$ da ordem de 0,76 indicando que $76 \%$ das variações na quantidade demandada de laranja no mercado atacadista são explicadas pelas variāveis incluídas no modelo de regressão.

Os coeficientes de curto prazo estimados para as variāveis preço real da laranja, preço real do abacaxi e quan tidade de laranjas defasada foram significantes a $99 \%$ de proba bilidade.

A elasticidade-preço da demanda, da ordem de -0,50 (demanda preço-inelástica), indica que uma variação nos preços de laranja causą uma variação em sentido inverso, menos que propor cional, na quantidade demandada.

Em relação às elasticidades cruzadas, o coeficí ente estimado para a variável preço real da banana no atacado não foi estatisticamente significante. Para o preço real do abacaxi, a elasticidade estimada, da ordem de 0,34, evidencia a existencia de baixo poder de competição entre esta fruta e a laranja.

o coeficiente da variável "dummy" $D_{0}$ para inter 
Tabela 10 - Estimativa dos parāmetros dos modelos de demanda de laranja, a nível de atacado. Estado da Bahia, 75/78

\begin{tabular}{|c|c|c|c|c|}
\hline \multirow{2}{*}{$\begin{array}{l}\text { Variāveis } \\
\text { Explicativas }\end{array}$} & \multicolumn{2}{|c|}{$\begin{array}{c}\text { Equações do modelo } \\
\text { dinâmico }\end{array}$} & \multicolumn{2}{|c|}{$\begin{array}{c}\text { Equações do modelo } \\
\text { estático }\end{array}$} \\
\hline & I & I I & I II & IV \\
\hline Intercepto & $\begin{array}{l}2,0560^{\star * *} \\
(4,09)\end{array}$ & $\begin{array}{l}1,9215^{\star \star *} \\
(5,05)\end{array}$ & $\begin{array}{l}10,2489^{\star \star \star} \\
(22,9)\end{array}$ & $\begin{array}{c}9,9834^{* \star \star} \\
(21,8)\end{array}$ \\
\hline$p_{t}^{c}$ & & & $\begin{array}{l}-0,2582 \\
(-0,94)\end{array}$ & $\begin{array}{l}-0,1726^{*} \\
(-1,97)\end{array}$ \\
\hline$p_{t}^{B}$ & $\begin{array}{l}-0,0484 \\
(-0,31)\end{array}$ & $\begin{array}{l}0,0184 \\
(0,14)\end{array}$ & $\begin{array}{l}0,4777^{* *} \\
(2,61)\end{array}$ & $\begin{array}{l}0,4671^{\star \star} \\
(2,62)\end{array}$ \\
\hline$P_{t}^{A}$ & $\begin{array}{l}0,3366^{* \star *} \\
(3,90)\end{array}$ & $\begin{array}{l}0,1347^{*} \\
(1,51)\end{array}$ & $\begin{array}{l}0,2823^{* * *} \\
(3,48)\end{array}$ & $\begin{array}{l}0,2024^{\star \star} \\
(2,27)\end{array}$ \\
\hline$P_{t}^{L}$ & $\begin{array}{l}-0,5032^{\star \star \star} \\
(-3,63)\end{array}$ & $\begin{array}{l}-0,4130^{\star \star \star} \\
(-3,52)\end{array}$ & $\begin{array}{l}-0,5248^{* * *} \\
(-4,21)\end{array}$ & $\begin{array}{l}-0,6616^{\star \star \star} \\
(-6,61)\end{array}$ \\
\hline$D_{0}$ & $\begin{array}{l}-0,0084 \\
(-0,23)\end{array}$ & - & $\begin{array}{l}-0,1433^{\star *} \\
(2,12)\end{array}$ & - \\
\hline$D_{1}$ & - & $\begin{array}{l}0,1077^{* \star *} \\
(3,93)\end{array}$ & - & $\begin{array}{l}0,1769^{* *} \\
(2,61)\end{array}$ \\
\hline$Q_{t-1}$ & $\begin{array}{l}0,3505^{\star \star \star} \\
(2,52)\end{array}$ & $\begin{array}{l}0,4116^{* \star *} \\
(3,99)\end{array}$ & - & - \\
\hline W & - & - & $\begin{array}{l}-0,0095^{\star \star \star} \\
(-3,70)\end{array}$ & $\begin{array}{l}-0,0088^{* \star \star} \\
(-3,47)\end{array}$ \\
\hline $\mathrm{F}_{2}$ & $23,08^{\star \star \star}$ & $37,72^{\star \star \star}$ & $25,52^{\star \star * \star *}$ & $27,33^{\star \star \star}$ \\
\hline $\mathrm{R}$ & 0,76 & 0,83 & 0,81 & 0,82 \\
\hline d & 1,98968 & 2,3756 & 2,0882 & 2,0212 \\
\hline $\mathrm{h}$ & 0,09 & $-1,63$ & - & - \\
\hline
\end{tabular}

OBS.: Os nümeros entre parēnteses referem-se aos valores de $t$ de Student. Os asteriscos indicam o nível de significância a $1 \%(* * *), 5 \%(* *)$ e $10 \%(*)$. d e $h$ referem-se aos valores dos testes de Durbin-Watson. e de Durbin para autocorrelação, respectivamente. 
cepto não foi estatisticamente significante,não se podendo com cluir que haja deslocamentos da demanda devido a um maior con sumo de laranjas no verão (dezembro a março).

O coeficiente da variável quantidade defasada, da ordem de 0,35 e altamente significante, evidencia que as com pras de laranja pelos atacadistas são feitas levando-se em con sideração as espectativas formadas em função de compras anterio res.

A elasticidade de ajustamento $(\lambda)$, estimada a partir do coeficiente da variāvel quantidade de laranja defasa da, da ordem de 0,65, indica a proporção de desequilíbrio que é removida em um período. Sendo o desequilíbrio total igual à diferença entre a quantidade de equilibrio a longo prazo e a quantidade efetivamente adquirida no mercado atacadista, podese, a partir da relação (4.2.4.), estimar o tempo necessārio para que a quantidade demandada no curto prazo se iguale a uma proporção a da quantidade desejada no longo-prazo. Para $\alpha$ igual a $95 \%$ e sendo $\lambda$ igual a 0,65 tem-se que o temponecessário para que a quantidade corrente se iguale a $95 \%$ da quantidade de equi líbrio no longo prazo é de, aproximadamente, 3 meses.

Da equação I, dividindo-se pela elasticidade de ajustamento os parāmetros estimados para intercepto e para as variāveis $P_{t}^{B}$, $P_{t}^{A}, P_{t}^{L}$ e $D_{0}$, obtem-se uma estimativa da função de demanda de longo prazo:

$\log Q_{t}^{*}=3,17-0,07 \log P_{t}^{B}+0,52 \log P_{t}^{A}-0,77 \log P_{t}^{L}-0,01 D_{0}$ 
A aplicação da estatística d de Durbin-Watson, a 95\% de probabil idade, e da estatística h de Durbin, permite con cluir pela não rejeição da hipótese de autocorrelação nula.

Na equação II, a variāvel "dummy" $D_{0}$ foi substi tuĩda por uma "dummy" ( $\left.D_{1}\right)$ para captar efeito de deslocamento da demanda quando predomina no mercado a laranja 'Bahia' $\left(D_{1}=1\right)$ ou a laranja 'Pera' $\left(D_{1}=0\right)$.

0 coeficiente de determinação, da ordem de 0,83 , denota um alto grau de explicação dás variāveis consideradas no modelo. As estimativas dos parāmetros evidenciaram resulta dos parecidos com os obtidos na equação I, ou seja, inelastici dade preço da demanda (igual a $-0,41$, significante a $1 \%$ ) e ba xa competitividade entre laranja e abacaxi (elasticidade cruza da igual a 0,13, significante a 10\%). Em relação à variável preço real da banana, a elasticidade estimada não diferiu esta tisticamente de zero. O coeficiente da variāvel "dummy" $\left(D_{1}\right)$, da ordem de 0,11 e significante a $1 \%$ de probabilidade, indica que a função de demanda desloca-se para cima quando a laranja'Bahia' passa a predominar no mercado, em relação à laranja 'Pera'. Es te resultado evidencia que, a preços constantes, maiores quan tidades de laranja são adquiridas quando a variedade 'Bahia' predomina no mercado, sugerindo uma preferéncia por este varie dade em relação à 'Pera'. A estimativa do parāmetro da variāvel quantidade defasada foi da ordem de 0,41, significativa a $1 \%$. A este valor, corresponde uma elasticidade de ajustamento igual a 0,59 . 
Pode-se, então, expressar a função de longo prạ zo dividindo-se as estimativas dos parāmetros da equação II pe la respectiva elasticidade de ajustamento:

$\log Q_{t}^{*}=3,27+0,03 \log P^{B}+0,23 \log P^{A}-0,70 \log P^{L}+$ $0,18 D_{1}$

0 teste de Durbin-Watson (d) foi não significa tivo para a ocorrencia de autocorrelação positiva ao nível de 95\% de probabilidade e inconclusivo quanto à existēncia de au tocorrelação negativa. A estatīstica h de Durbin, da ordem de -1,63, sugere a ocorrencia de baixa correlação serial.

As equações III e IV referem-se aos modelos está ticos de demanda. Procedimento idēntico aoutiłizado nas equações I e II foi adotado em relação à definição das variáveis "dummy".

os coeficientes de determinação $\left(R^{2}\right)$ foram da or dem'de 0,81 e 0,82 respectivamente para as equações III e IV, indi cando alto grau de explicação das variāveis incluídas nas equa ções de regressão.

Em relação à ocorrēncia de autocorrelação, o tes te de Durbin-Watson foi não significativo, ao nível de 5\%, tan to para a equação II quanto para a equação IV.

As estimativas dos parāmetros da equação III fó ram significantes ao nível de $1 \%$, exceto para as variáveis pre ço real da banana $\left(P_{t}^{B}\right)$ e "dummy" $\left(D_{0}\right)$, significantes a $5 \%$. Em relação à equação IV, as elasticidades estimadas foram signifí cantes a $1 \%$ para preço real da laranja $\left(P_{t}^{L}\right)$ e Tendēncia (W), a 
$5 \%$ para preço real da banana $\left(P_{t}^{B}\right)$, preço real de abacaxi ( $P_{t}^{A}$ ) e "dummy" $\left(D_{1}\right)$, e a $10 \%$ para a variável preço real de tangerina $\left(P P_{t}^{C}\right)$.

Comparando-se as equações do modelo dināmico de demanda (I e II) com as do modelo estático (III e IV), algumas observações podem ser feitas em relação ao comportamento das variāveis.

As elasticidades estimadas para preço real de banana foram bem superiores, e significantes, nos modelos estāti cos do que nas equações do modelo dinámico. Possivelmente, nos modelos I e II, a variável preço real da banana esteja captan do o efeito das variāveis preço real de tangerina $\left(P_{t}^{C}\right)$ e Ten dēncia (W), excluídas das equações. Isto pode ser observado, tambēm, comparando-se as equações I e II da Tabela 10 com as equações C e D do Apēndice 4.

0 coeficiente da variāvel "dummy" $D_{0}$, na equação III, igual a $-0,14$, sugere diferença nos níveis de consumo de laranja entre inverno e verão.

Em relação à variāvel preço real da laranja, as elasticidades-preço de curto-prazo estimadas através das equa ções III e IV não diferem muito das obtidas através das equa ções I e II. Isto sugere que tanto os modelos dināmicos quanto os modelos estáticos permitiram boas estimativas da elastici dade-preço de curto-prazo. 
5.3. Dificuldades e limitações.

Algumas dificuldades e limitações ocorreram na anālise das relações de oferta e demanda de laranja no Estado da Bahia.

Em relação à oferta, ó primeiro problema encontra do foi a escassez de dados que limitou a anālise de fatores con siderados relevantes: 0 problema da autocorrelação, evidenciado na maioria dos modelos alternativos testados (Apéndice 3), tam bém constituiu-se em fator limitante ao uso do método de mini-l mos quadrados ordinārios. Outra constatação importante foi a observação de ocorrencia de correlação alta entre variāveis in dependentes (Apēndice 5), sugerindo a ocorréncia de multicolinea ridade, o que afeta a precisão das estimativas dos parāmetros. Este problema poderia, talvez, ser contornado caso houvesse a possibilidade de se aumentar o tamanho da amostra, permitindo, assim, detectar a influência de variāveis cujos parâmetros não se mostraram significantemente diferentes de zero.

Quando à demanda, a principal limitação referiuse à exclusão de uma variāvel indicadora de renda da população; por insuficiència de dados. 
6. CONCLUSÕES

os modelos do tipo nerloviano utilizados para es timar oferta e demanda apresentaram elevado grau de explicação para o caso da Iaranja no Estado da Bahia. Contudo, algumas di ficuldades se evidenciaram, geradas, principalmente, pela não disponibilidade de dados suficientes que permitissem detectar a influência de alguns fatores que interagem no comportamento de produtores e compradores.

Neste capitulo, são apresentadas as conclusões obtidas da análise da influéncia dos preços na demanda e na resposta da ārea, bem como as dificuldades e limitações surgi das.

Em relação à oferta, os resultados surgerem que, no curto prazo (definido como um período de produção), o preço 
da laranja e o preço do fumo não são relevantes na determinação da ārea colhida de laranja. Considerando-se o longo prazo, as estimativas das elasticidades-preço para os períodos 1950/1965 a 1966/1977 permitem identificar uma mudança de comportamento dos citricultores em relação a o preço: para o período 1950/1965 obteve-se elasticidade-preço negativa, fato incoerente com a teoria económica mas que pode ser explicado pelo comportamento decrescente do preço do fumo elevando a relação $\left(P L_{-3} / P_{t-3}^{F}\right)$ mes mo a preços decrescentes da Iaranja. Para o período 1966/1977, a elasticidade-preço da oferta de laranja no longo-prazo foi positiva, embora inelästica.

A caracterização da citricultura baiana ao longo do periodo analisado permite entender melhor o comportamento da ārea colhida em relação aos preços. Até o fim do primeiro pe ríodo (1950/1965) a citricultura pode ser caracterizada como atividade de "fundo de quintal" tal a sua inexpressividade co mo cultura comercial, exceto por iniciativas isoladas de alguns poucos produtores que jā vinham estabelecendo pomares em bases empresariais, principalmente na região Recōncavo Baiano. A inexistência de um mercado estāvel para a laranja provavelmente tenha determinado este tipo de citricultura, acentuada ainda pe las fracassadas experiéncias anteriores quando a doença conhecida como "tristeza" dizimou esta cultura. Muito provavelmente o comportamento da citricultura neste período não foi relevante mente influenciado pelos preços. O período $1966 / 1977$ representa a grande fase de expansão da citricultura, possivelmente pressio 
nada por uma demanda crescente de frutas nas zonas de grande ex pansão urbana, principalmente na região metropolitana de Salvador onde se acentuou o crescimento industrial. Parece razoāvel admitir que a necessidade de efetuar investimentos em novos pomares tenha tornado os produtores mais sensiveis às variações de preço, como modo de reduzir a incerteza quanto aos retornos futuros. A Variāvel tendéncia $(Z)$ incluỉda na regressão sugere que outros fatores devem ser considerados para explicar o com portamento dos citricultores em relação à expansão da ārea co Inida. Possivelmente, a inclusão de variáveis representativas de crédito rural e assisténcia técnica melhorem consideravelmente o modelo especificado. Em relação ao crédito rural, parece que a sua inclusão na añ̄i ise seja relevante, principalmente quando se admite as limitações quanto à disponibilidade de recursos próprios dos produtores para investimento em novos plantios e, ainda mais, quando se considera que os subsídios implícitos no crēdito rural a taxas negativas de juros podem estar aumentando o valor presente dos fluxos de renda líquida futura, ainda que os preços de laranja estejam caindo no presente e, por força do modelo utilizado, devessem cair também no futuro. A elasticidade-preço da oferta de laranja no longo prazo, estimada para a Bahia, igual a 0,68 no período $1966 / 77$, foi bem superior à estimativa obtida por NAMEKATA (1977) para o Estado de São Paulo, em torno de 0,16 no perĩodo 1959/75, mostrando que os citricultores baianos são mais sensíveis a variações do preço da laranja do que os citricultores paulistas. Possivelmente, 
a menor elasticidade-preço da oferta de laranja em São Paulo es teja associada ao fato de que grande parte da produção destina - se à industria e, assim, aumentos da ārea cultivada podem es tar relacionados com aumentos na capacidade instalada da industria de processamento de laranja.

Estes resultados sugerem que um aumento no pre ço da laranja (devido a um deslocamento da demanda, por exemplo)s rā mais eficiente na Bahia do que em São Paulo, no sentido de aumentar a àrea colhida e, consequentemente, a quantidade de frutas ofertada.

Considere-se ainda que em alguns estados produtores, como São Paulo, a expansão de outras culturas, como a cana de-açūcar, por exemplo, poderā reduzir o crescimento da àrea cul tivada com laranja. Desde que os preços da laranja estejam cre cendo, isto traria vantagens em termos de ampliação da ārea cul tivada com laranja nas regiões citrīcolas do Estado da Bahia onde outras alternativas de produção são limitadas, entre ou. tros fatores pela estrutura fundiāria, caracterizada pela pre domināncia de pequenas propriedades.

Em relação à demanda, os resultados obtidos mos traram a validade de utilização de modelos dināmicos para estị mar as elasticidades de longo prazo.

As estimativas da elasticidade-preço de curto-pra zo, obtidas dos modelos dinãmico e estātico, apresentaram resultados semelhantes evidenciando, ainda, que no curto prazo a demanda é preço-inelàstica. 
Dos resultados obtidos, conclue-se que os atacadistas são sensíveis a variações no preço da laranja, reduzin do as quantidades adquiridas quando os preços se elevam. Este resultado sugere que, no longo prazo, politicas de preço poderão ser relativamente eficazes no aumento do consumo de laranjas.

Quanto às elasticidades cruzadas, as estimativas obtidas a partir do modelo dināmico evidencian que variações nos preços de banana e tangerina não afetam a demanda por laranja. Em relação ao abacaxi, embora haja sensibilidade a va-l riações no seu preço, as possibilidades de substituição de laranja por esta fruta são baixissimas. No modelo estático, evidenciou-se uma relação de complementariedade entre laranjas e tangerina, equanto à banana e ao abacaxi,evidenciou-se que são competitivas com a laranja.

Como esperado, evidenciou-se que os efeitos dos preços nas quantidades de laranja adquiridas a nivel de atacado são mais intensas no longo prazo do que no curto prazo.

Um outro aspecto abordado refere-se à observação de que a função de demanda desloca-se para cima quando a varie dade de laranja 'Bahia' predomina no mercado, em relação à la ranja 'Pera', sugerindo haver uma preferência por aquela varie dade. 


\section{SUMMARY}

In order to determine the short-run and long-run elasticities of supply and demand of oranges for the State of Bahia, models of partial adjustment with distributed lags were fitted, using least square techriques. The demand for orange was considered at the wholesale level. The supply of oranges was fitted considering harvested area as a proxy for expected quantity supplied.

Real prices of orange and tobacco, lagged for three years, were the independent variables considered in estimating the harvested area function. In order to improve the fitness of the supply function it was introduced a dummy variable which broke down the observations into two sub-periods. The area harvested showed negative correlation with the lagged 
price of orange in the first period (when orange were not a commercial crop) and positive correlation, as expected, in the second period (1965-1977) when orange became a major commercial crop in the region. Problems of multicolinearity may have occured due to high correlation among the independent variables.

The demand function for orange at the wholesale level, included the following independent variables: prices of orange, tangerine, banana and pinaples and the lagged (one month), quantity of orange. A high proportion of the variation on the quantity of orange acquired at the wholesale level was explainned by the model. The price elasticity of demand for orange was found to be low (price inelastic). Pinaple was found to be competitive with orange but the value of the cross price elasticity was found to be low. The inclusion of a dummy variable to detect variations on quantity demanded due to seasonal changes (winter-summer) did not ' show significant improvement on the model. The introduction of a dummy variable to measure shifts on demand due to prevalence of the variety 'Bahia" over the variety 'Pera' shawed a significant improvement on the perfomance of the model.

Finally, the estimates for price-elasticities of demand were found not to differ when a dinamic model was utilized instead of the estatic one. 
69.

8. LITERATURA CITADA

ANUARIO ESTATISTICO DO BRASIL, 1977. Rio de Janeiro, Fundação IBGE, v. 38, $848 \mathrm{p}$.

BATEMAN, M.J., 1970. Supply relations for perennial crops in less developed areas. In: WHARTON JR, C.R., Coord. Subsistence agriculture and economic development. Chicago, Aldine Publishing, p. 243-53.

BRASIL. Fundação Getūlio Vargas, (1977): Preços Recebidos pelos agricultores.

BRASIL. Ministērio da Agricultura, 1976. Sērie Estatîsticas Agropecuārias. Brasîlia, SUPLAN, 13(3):9. 
BRASIL. Ministērio da Agricultura, 1978. Produção e comércio atacadista de citros no Brasil. Brasilia, COBAL, 72 p.

CARVALHo, M.L., 1974. A citricultura no RecóncavoBaiano. Revista Planejamento na Bahia, Salvador, $\underline{2}(1): 53-8$.

COCHRAN, D.e G.H. ORCUTT, 1949. Application of least aqua res regression to relationships containing autocorrelated error terms. Journal of American Statistical Association. 44:36-61.

FRENCH, B.C. e R.G. BRESSLER, 1962. The 1emon cycle. Jounal of Farm Economics, Menasha, 44(4):1021-36.

FULLER, W.A. e J.E. MARTIN. 1961. The effects of autocorre lated errors on the statistical estimation of distributed lag models. Journal of Farm Economics, Menasha, 43(1):7182.

GRILLICHES, Z., 1967. A note serial correlation bias in estima tes of distributed 1ags. Econometrica, Bristol, 29(1):63-65.

HENDERSON, J.M. e R.E. QUANDT, 1976. Teoria Microeconómica. São Paulo, Livraria Pioneira Editora, $417 \mathrm{p}$.

JOHNSTON, J., 1972. Econometric Methods. 2.ed. New York, McGraw-Hill.

LARANJA ao natural: Brasil quase ausente destas exportações, 1979. Citrus, São Paulo, I(18/19):10-8, nov./dez. 
MERCADO externo quer nossas frutas citricas, 1978. Citrus, São Paulo, 2(2):10-3, mar/abr.

MORAIS, E.L. de e M. de L.M. MEDEIROS. 1978. A participação brasileira no mercado internacional de laranja e suco concentrado de laranja: comportamento recente e perspectivas. Brasilia, SUPLAN, $62 \mathrm{p}$.

NAMEKATA, T., 1977. Modelos alternativos de oferta: o caso dos citros no estado de São Paulo. Viçosa, UFV, 81 p. (Tese de Mestrado).

NERLOVE, M., 1958. Distributed lags and estimation of long-run supply and demand elasticities: Theoretical considerations. Journal of Fam Economics, Menasha, 40(2):301-11.

NERLOVE, M. e W. ADDISON, 1958. Statistical estimation of long-run elasticities of supply and demand. Journal offarm Economics, Menasha, 34:816-79.

NORONHA, J.F., J.G. GASQUES e A.A. AMARO, 1978. Anālise Econo métrica da oferta e da demanda de laranja no Estado de São Paulo. Revista de Economia Rural, Brasîlia, 16(2):79-96.

PASSOS, 0.S. e A.P. da CUNHA SOBRINHO, 1970. Cultura dos citros no Estado da Bahia. Cruz das Almas, IPEAL, $36 \mathrm{p}$.

PASSOS, 0.S. e A.A. SALIBE, 1978. Citrus Industry of South America with special reference to Brazil. $33 \mathrm{p}$. (No prelo).

REDESCOBRINDO velhos clientes, 1978. Citrus, São Paulo, I (4):11-3. ju1./ago. 
REUTHER, W., 1977. Citrus. In: Ecophysiology of tropical crops. New York, Academic Press, cap. 15, p. 409-39.

AS SURPRESAS do primeiro semestre. 1979. Citrus. São Paulo, I (14/15): 10-8. jul./ago. 
73.

A P E N D I C E S 
Apēndice 1

Tabela 1.1 - Area e quantidade colhidas de laranja, preços re ais de laranja e fumo. Estado da Bahia, 1947/77.

\begin{tabular}{|c|c|c|c|c|}
\hline ANO & $\begin{array}{l}\text { Area colhida } \\
\text { de laranja } \\
\text { (ha) }\end{array}$ & $\begin{array}{l}\text { Qde colhida } \\
\text { de iaranja } \\
\text { (1000 frutos) }\end{array}$ & $\begin{array}{c}\text { Preçoreal } \\
\text { de laranja } \\
(*)\end{array}$ & $\begin{array}{l}\text { Pref̧o real } \\
\text { do fumo } \\
\left({ }^{*}\right)\end{array}$ \\
\hline $\begin{array}{l}1947 \\
1948 \\
1949 \\
1950 \\
1951 \\
1952 \\
1953 \\
1954 \\
1955 \\
1956 \\
1957 \\
1958 \\
1959 \\
1960 \\
1961 \\
1962 \\
1963 \\
1964 \\
1965 \\
1966 \\
1967 \\
1968 \\
1969 \\
1970 \\
1971 \\
1972 \\
1973 \\
1974 \\
1975 \\
1976 \\
1977\end{array}$ & $\begin{array}{l}2.225 \\
2.325 \\
2.414 \\
2.493 \\
2.530 \\
2.534 \\
2.517 \\
2.574 \\
2.575 \\
2.749 \\
2.970 \\
2.936 \\
2.917 \\
3.027 \\
3.111 \\
2.736 \\
2.816 \\
2.995 \\
3.303 \\
3.846 \\
4.377 \\
4.724 \\
5.066 \\
5.425 \\
5.692 \\
6.111 \\
6.397 \\
7.000 \\
8.215 \\
8.550 \\
9.000\end{array}$ & $\begin{array}{l}131.372 \\
133.776 \\
156.914 \\
168.025 \\
155.464 \\
161.135 \\
159.826 \\
157.115 \\
168.719 \\
181.001 \\
215.779 \\
217.597 \\
211.906 \\
211.712 \\
203.080 \\
209.538 \\
213.879 \\
235.362 \\
359.315 \\
289.406 \\
317.218 \\
335.635 \\
372.345 \\
388.857 \\
392.319 \\
415.792 \\
398.589 \\
488.628 \\
591.480 \\
589.950 \\
552.000\end{array}$ & $\begin{array}{l}20,45 \\
23,66 \\
23,39 \\
24,03 \\
24,82 \\
21,86 \\
23,03 \\
23,07 \\
24,35 \\
24,86 \\
27,53 \\
31,54 \\
28,19 \\
26,75 \\
26,35 \\
26,10 \\
24,73 \\
21,87 \\
21,59 \\
23,83 \\
21,95 \\
19,48 \\
21,03 \\
22,22 \\
22,15 \\
21,89 \\
27,77 \\
25,71 \\
20,99 \\
24,77 \\
17,97\end{array}$ & $\begin{array}{r}548,64 \\
473,21 \\
452,45 \\
591,07 \\
515,92 \\
609,47 \\
577,89 \\
648,39 \\
660,44 \\
648,37 \\
531,77 \\
655,83 \\
951,91 \\
948,71 \\
957,45 \\
1.046,58 \\
650,13 \\
522,93 \\
694,32 \\
417,08 \\
452,97 \\
580,03 \\
612,88 \\
534,92 \\
514,02 \\
671,22 \\
620,37 \\
449,19 \\
527,60 \\
695,50 \\
993,45\end{array}$ \\
\hline
\end{tabular}

Fonte: BRASIL. Ministério da Agricultura (1976) ANUARIO ESTATISTICO DO BRASIL (diversos números)

(*) Preços corrigidos pelo Indice Geral de Preços disponibilidade interna (média 1965/1976 * 100) 


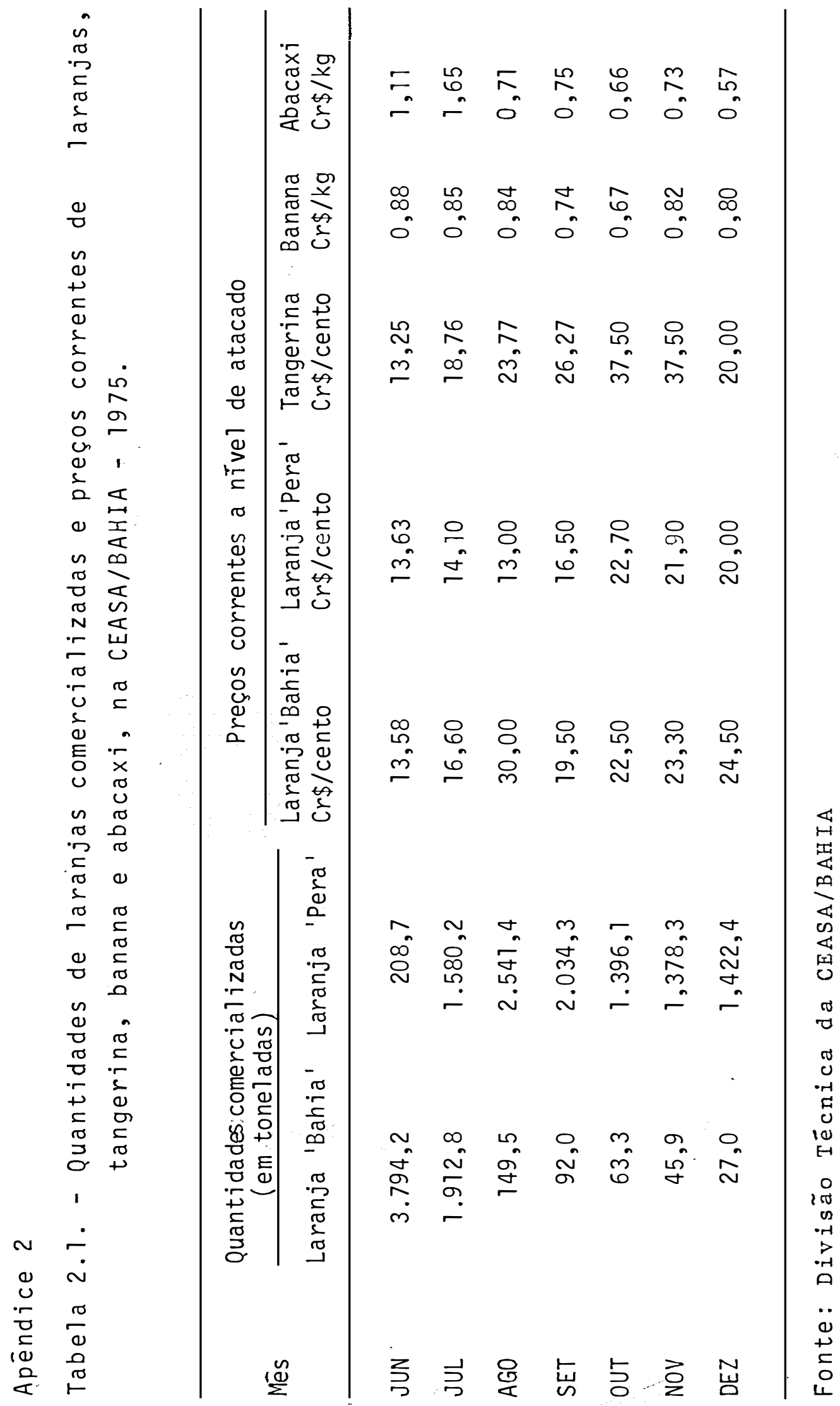




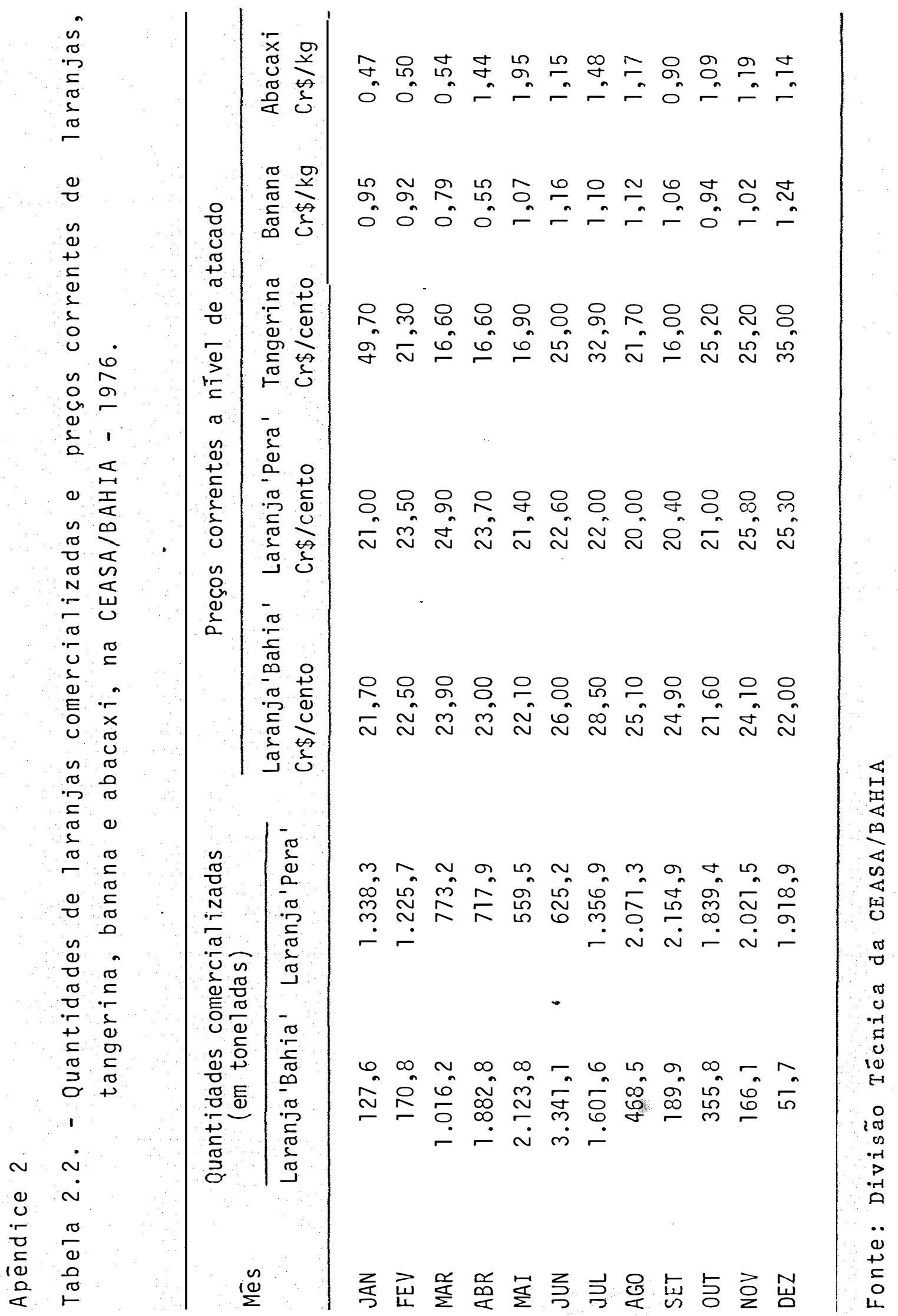




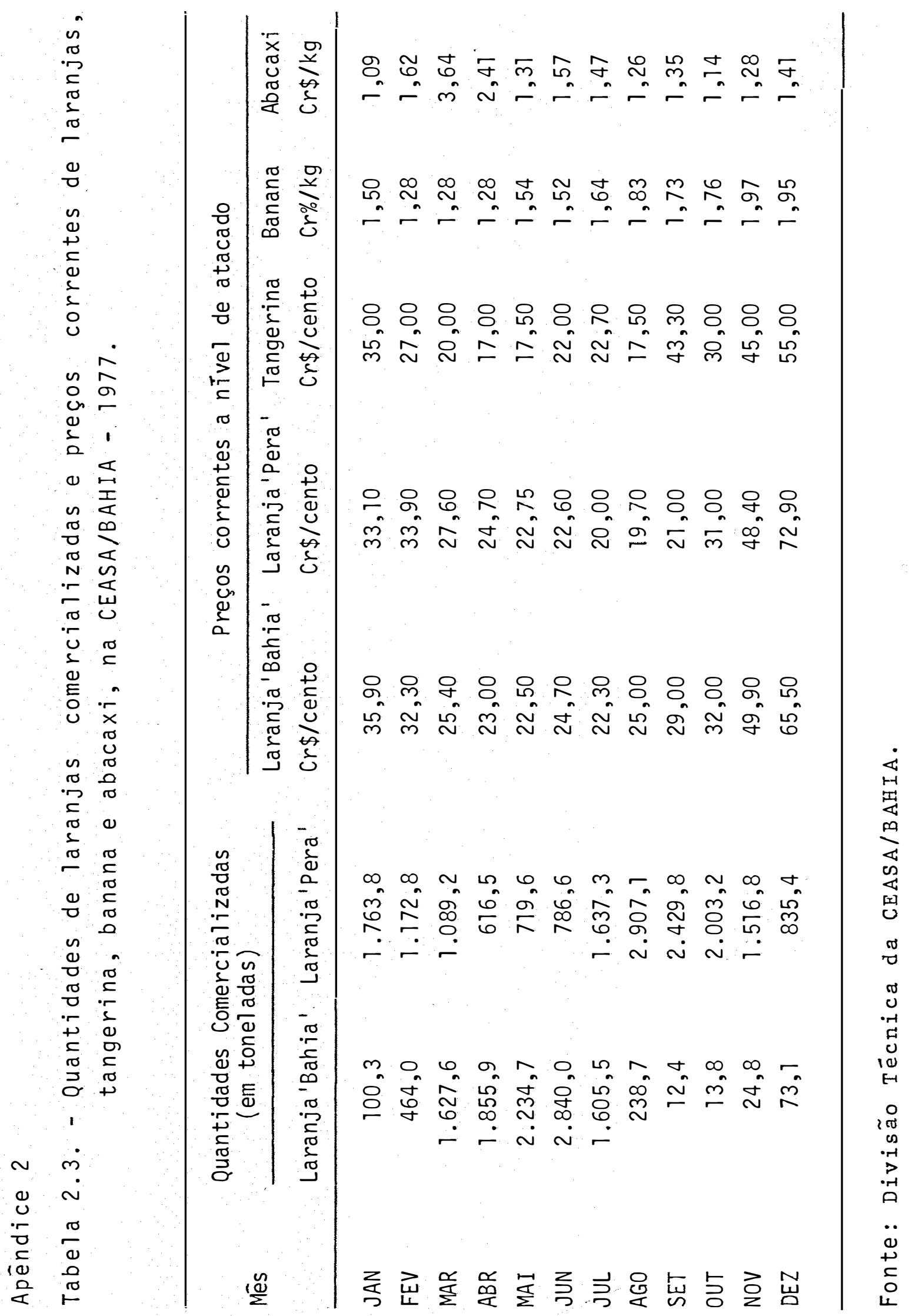




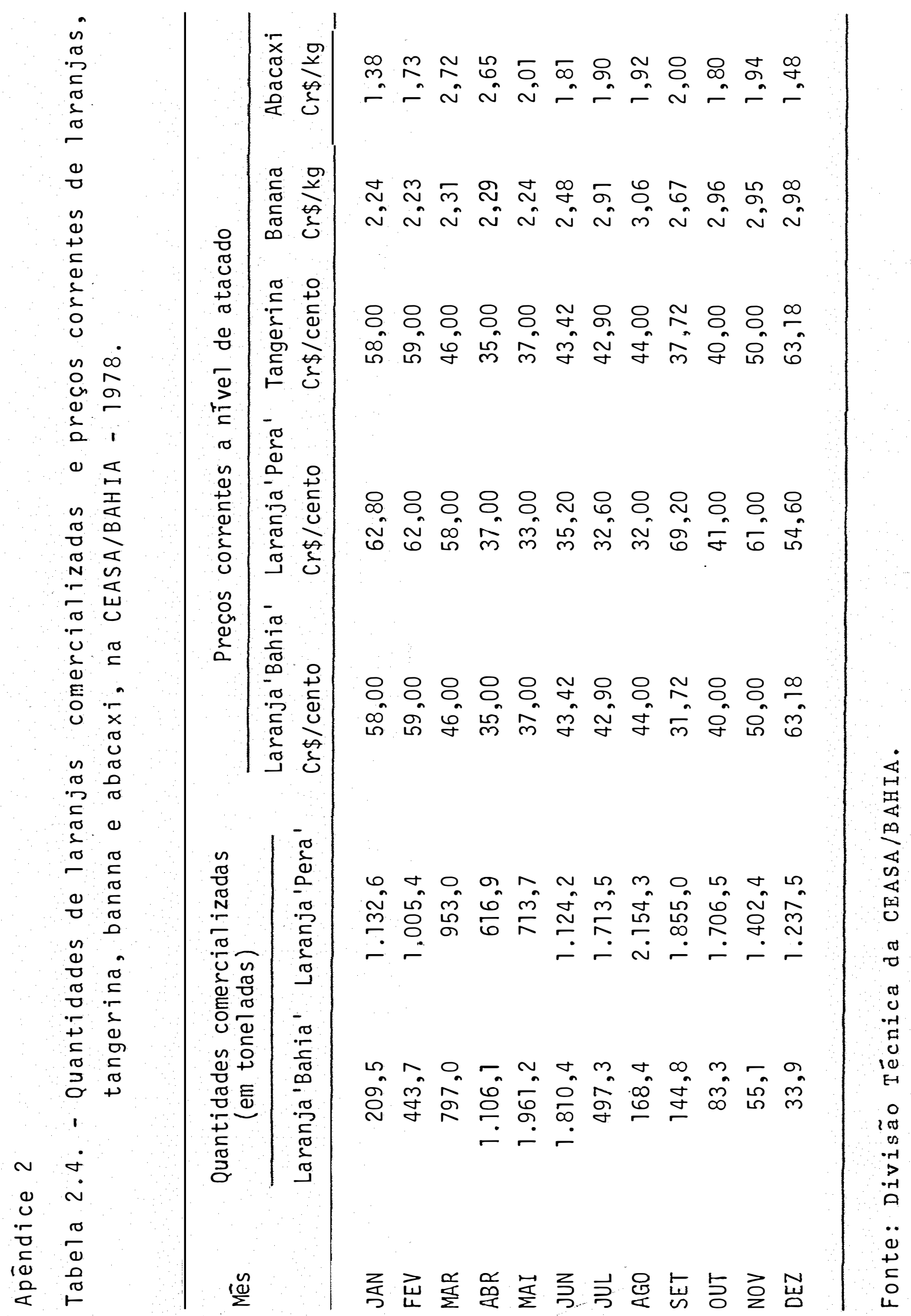


Apèndice 3

Tabela 3.1. Equações alternativas estimadas de resposta de ārea colhida de laranja. Estado da Bahia. 1947/ 77.

\begin{tabular}{|c|c|c|c|}
\hline \multirow{2}{*}{$\begin{array}{l}\text { Variāveis } \\
\text { Explicativas }\end{array}$} & \multicolumn{3}{|c|}{$M 0 d e 10 s$} \\
\hline & $A$ & B & C \\
\hline Intercepto & $\begin{array}{r}3,651 \\
(0,82)\end{array}$ & $\begin{array}{l}3,651)^{* \star \star \star} \\
(0,82)^{-1}\end{array}$ & $\begin{array}{l}2,1894^{* \star *} \\
(1,12)\end{array}$ \\
\hline$P_{t-3}^{L} / P_{t-3}^{F}$ & $\begin{array}{l}0,1822 \star \star \\
(1,98)\end{array}$ & $\begin{array}{c}0,0244 \\
(0,39)\end{array}$ & $\begin{array}{c}0,0069 \\
(0,06)\end{array}$ \\
\hline Z & $\begin{array}{l}0,0225 * * \star \\
(3,47)\end{array}$ & $\begin{array}{l}0,0234 * \star \star \\
(5,78)\end{array}$ & $\begin{array}{l}0,0056 \\
(0,82)\end{array}$ \\
\hline D & & & $\begin{array}{l}-0,1079 \\
(-0,21)\end{array}$ \\
\hline$D P_{t-3}^{L}$ & & & $\begin{array}{l}0,0482 \\
(0,33)\end{array}$ \\
\hline DT & & $\begin{array}{l}-0,0164 * \star * \\
(-6,22)\end{array}$ & \\
\hline$A_{t-3}$ & $\begin{array}{l}0,6814^{* \star \star *} \\
(4,42)\end{array}$ & $\begin{array}{l}0,5454 * \star \star \\
(5,54)\end{array}$ & $\begin{array}{l}0,7592 * \star * \\
(6,45)\end{array}$ \\
\hline$F$ & $177,55^{\star \star \star}$ & $352,21 * \star \star$ & 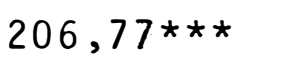 \\
\hline$R^{2}$ & 0,957 & 0,983 & 0,979 \\
\hline d & 0,6681 & 1,3027 & 1,1563 \\
\hline h & 5,90 & 2,14 & 2,79 \\
\hline$T^{2}$ & 0,69 & 0,39 & 0,47 \\
\hline
\end{tabular}

OBS: Os nūmeros entre parēnteses referem-se aos valores de $t$ Student. Os asteriscos indicam o nível de significància a $1 \%(* *), 5 \%(* *)$ e $10 \%\left({ }^{*}\right)$. d e $h$ e $T^{2}$ referem-se aos valores dos testes de Durbin-Watson, de Durbin, e de Theil-Nagar para autocorrelação, respectivamente. 
Apēndice 4

Tabela 4.1. Equações alternativas do modelo dināmico de demanda de 1 a ranja, a nível de atacado, Estado da Bahia, 1975/78.

\begin{tabular}{|c|c|c|c|c|}
\hline \multirow{2}{*}{$\begin{array}{l}\text { Variāveis } \\
\text { Explicativas }\end{array}$} & \multicolumn{3}{|c|}{ Mod e $10 \mathrm{~s}$} & \multirow[b]{2}{*}{ D } \\
\hline & $A$ & B & C & \\
\hline Intercepto & $\begin{array}{l}5,8394 * \star \star \\
(4,76)\end{array}$ & $\begin{array}{l}5,0135^{\star \star \star} \\
(5,07)\end{array}$ & $\begin{array}{l}8,0258^{\star \star \star} \\
(5,77)\end{array}$ & $\begin{array}{l}6,5053^{\star \star \star} \\
(5,76)\end{array}$ \\
\hline$p^{\top}$ & $\begin{array}{l}-0,2020 \\
(-2,24)\end{array}$ & $\begin{array}{l}-0,1359 \\
(1,70)\end{array}$ & $\begin{array}{l}-0,2588 \\
(-3,02)\end{array}$ & $\begin{array}{l}-0,1823^{* \star} \\
(-2,34)\end{array}$ \\
\hline$p^{B}$ & $\begin{array}{l}0,0346 \\
(0,22)\end{array}$ & $\begin{array}{l}0,0672 \\
(0,51)\end{array}$ & $\begin{array}{l}0,3757 * \star \\
(1,99)\end{array}$ & $\begin{array}{l}0,3179^{* \star} \\
(1,93)\end{array}$ \\
\hline$p^{A}$ & $\begin{array}{l}0,2636 * * * \\
(2,98)\end{array}$ & $\begin{array}{l}0,1057 \\
(1,19)\end{array}$ & $\begin{array}{l}0,2485^{\star \star \star} \\
(03,04)\end{array}$ & $\begin{array}{l}0,1108^{*} \\
(1,32)\end{array}$ \\
\hline$p^{L}$ & $\begin{array}{l}-0,3313^{* \star} \\
(-2,17)\end{array}$ & $\begin{array}{l}-0,3091^{\star \star} \\
(-2,38)\end{array}$ & $\begin{array}{l}-0,3988^{\star \star \star} \\
(-2,79)\end{array}$ & $\begin{array}{l}-0,3752^{\star \star \star} \\
(-2,99)\end{array}$ \\
\hline $\mathrm{D}_{0}$ & $\begin{array}{l}-0,0308 \\
(-0,38)\end{array}$ & & $\begin{array}{l}-0,7747 \\
(-1,01)\end{array}$ & \\
\hline$D_{1}$ & & $\begin{array}{l}0,2235^{\star \star \star} \\
(3,53)\end{array}$ & & $\begin{array}{l}0,2020^{* \star *} \\
(3,34)\end{array}$ \\
\hline$Q_{t-1}$ & $\begin{array}{l}0,3883^{\star \star \star} \\
(2,91)\end{array}$ & $\begin{array}{l}0,4385^{\star \star \star} \\
(4,30)\end{array}$ & $\begin{array}{l}0,2294^{*} \\
(1,68)\end{array}$ & $\begin{array}{l}0,3438^{\star \star \star} \\
(3,29)\end{array}$ \\
\hline$T$ & & & $\begin{array}{l}-0,0075^{\star \star} \\
(-2,70)\end{array}$ & $\begin{array}{l}-0,0056^{\star \star} \\
(-2,33)\end{array}$ \\
\hline $\mathrm{F}$ & $22,19^{\star \star \star}$ & $31,80^{\star \star \star}$ & $23,39^{\star \star \star}$ & $31,40^{\star \star \star}$ \\
\hline$R^{2}$ & 0,787 & 0,84 & 0,82 & 0,86 \\
\hline d & 2,0479 & 2,4032 & 2,2628 & 2,5774 \\
\hline$h$ & $-0,3227$ & $-1,7752$ & $-1,91$ & $-2,58$ \\
\hline
\end{tabular}

OBS.: Os nümeros entre parénteses referem-se aos valores de $t$ de Student. Os asteriscos indicam o nivel de significáncia a $1 \%(* *), 5 \%(* *)$ e $10 \%(*)$. d.e $h$ são: os valores dos tes tes de Durbin-Wațs on e Durbim para autocorrelação, respectivamente. 
81.

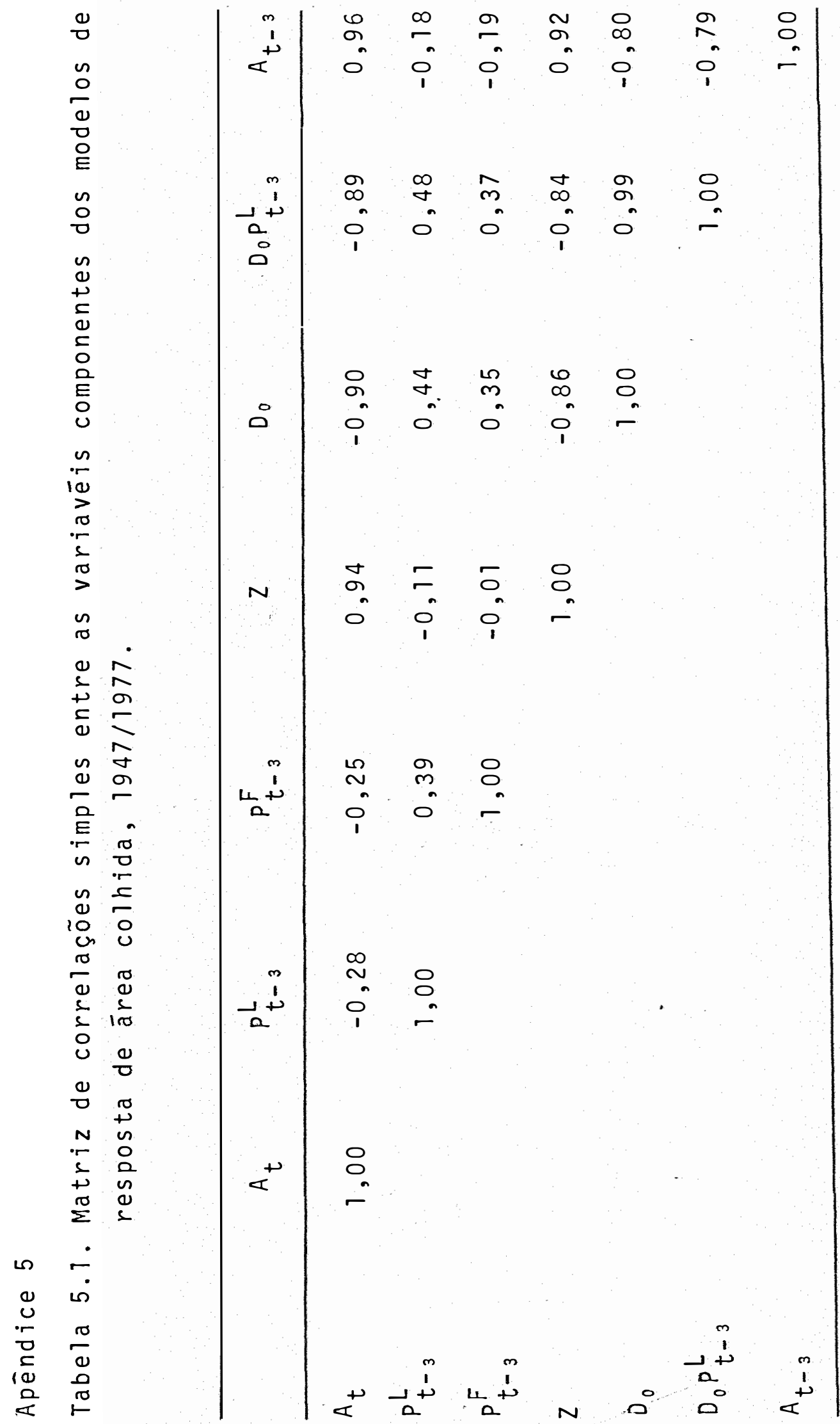




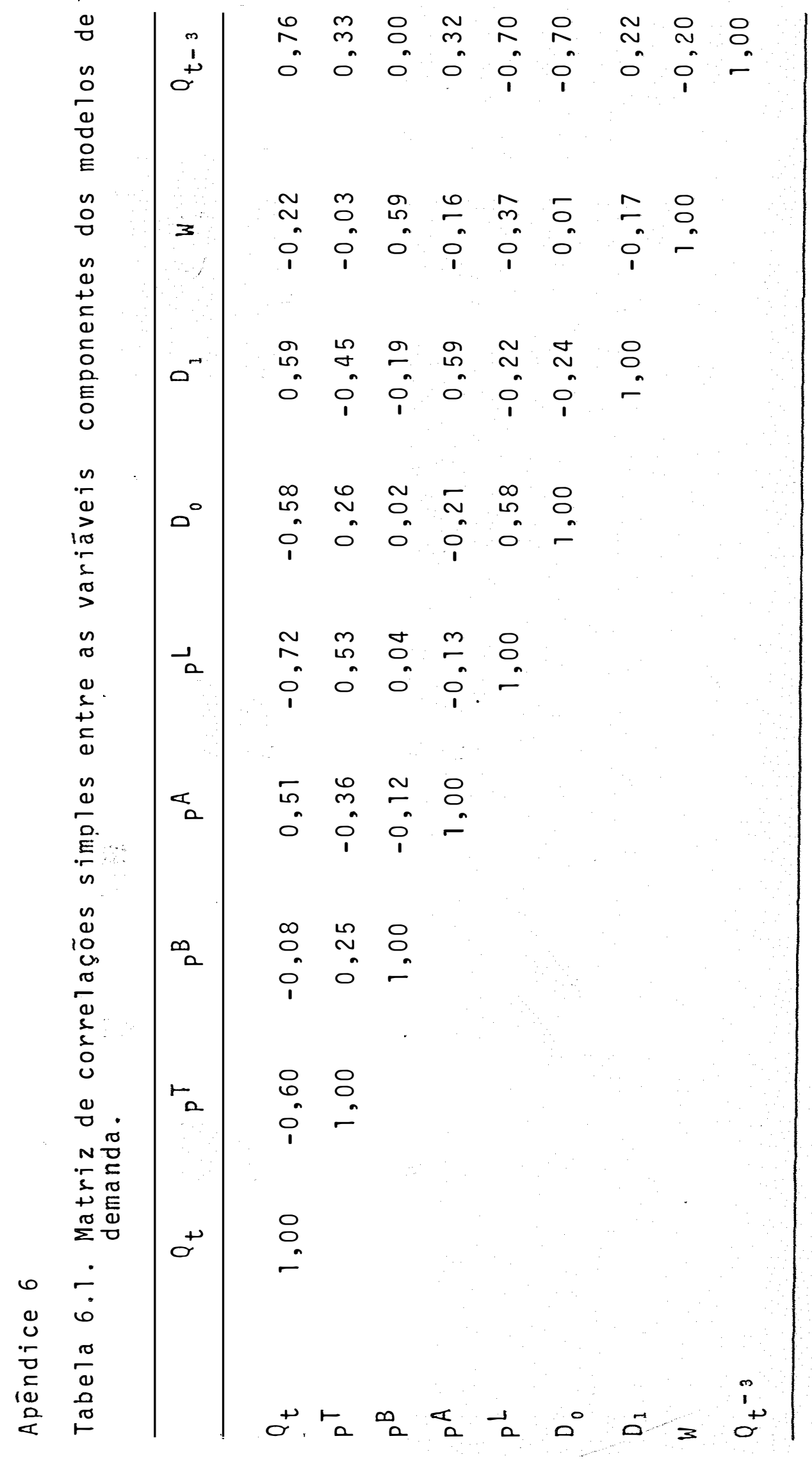

